\title{
A CONSIDERATION OF CERTAIN BULBAR, MID- BRAIN, AND CEREBELLAR CENTERS AND FIBER TRACTS IN BIRDS ${ }^{1}$
}

\author{
ESTHER BLICK SANDERS \\ Laboratory of Comparative Neurology, Department of Anatomy, \\ University of Michigan \\ FIFTEEN FIGURES
}

CONTIENTS

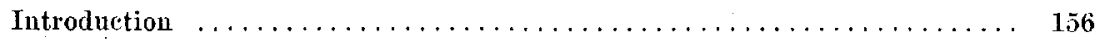

Materials and methods $\ldots \ldots \ldots \ldots \ldots \ldots \ldots \ldots \ldots \ldots \ldots \ldots \ldots \ldots \ldots \ldots$

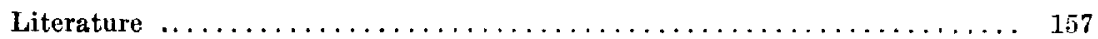

Deseription of nuclear masses and fiber paths $\ldots \ldots \ldots \ldots \ldots \ldots \ldots \ldots \ldots$

Nuelei and root fibers of the eye-muscle nerves $\ldots \ldots \ldots \ldots \ldots \ldots \ldots \ldots, 165$

Oculomotor nuclei and root fibers $\ldots \ldots \ldots \ldots \ldots \ldots \ldots \ldots \ldots$

Trochlear nucleus and root fibers $\ldots \ldots \ldots \ldots \ldots \ldots \ldots$

Abducens nuclei and root fibers $\ldots \ldots \ldots \ldots \ldots \ldots \ldots \ldots \ldots$

Fiber connections of the eye-muscle nuclei $\ldots \ldots \ldots \ldots \ldots \ldots \ldots \ldots \ldots 17$

Tecto-bulbar tract $\ldots \ldots \ldots \ldots \ldots \ldots \ldots \ldots \ldots \ldots \ldots \ldots \ldots \ldots \ldots \ldots$

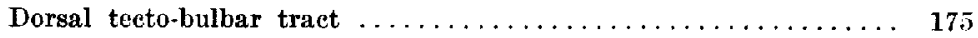

Ventral teeto-bulbar tract $\ldots \ldots \ldots \ldots \ldots \ldots \ldots \ldots \ldots \ldots \ldots \ldots$

Trigeminal nuclei and root fibers $\ldots \ldots \ldots \ldots \ldots \ldots \ldots \ldots \ldots \ldots$

Sensory nuelei of the trigeminal nerve $\ldots \ldots \ldots \ldots \ldots \ldots \ldots \ldots \ldots$

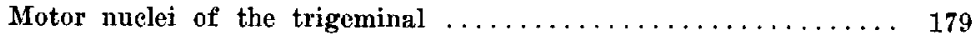

Cutaneous sensory root of the trigeminal $\ldots \ldots \ldots \ldots \ldots \ldots \ldots \ldots$

Mesencephalic and motor roots of the trigeminal $\ldots \ldots \ldots \ldots \ldots 18$

Secondary connections of the trigeminal centers $\ldots \ldots \ldots \ldots \ldots \ldots \ldots \ldots 185$

Internuelear fibers from sensory trigeminal nuclei $\ldots \ldots \ldots \ldots \ldots \ldots 185$

Trigemino-cerebellar connections $\ldots \ldots \ldots \ldots \ldots \ldots \ldots \ldots \ldots$

Secondary ascending trigeminal bundle. (trigemino-mesencephalie

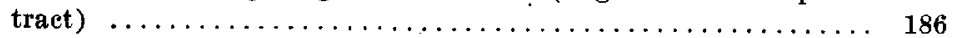

Quinto-frontal tract $\ldots \ldots \ldots \ldots \ldots \ldots \ldots \ldots \ldots \ldots \ldots \ldots \ldots \ldots \ldots$

Cerebello-motorius fibers $\ldots \ldots \ldots \ldots \ldots \ldots \ldots \ldots \ldots \ldots \ldots$

Nuclei and root fibers of the facial nerve $\ldots \ldots \ldots \ldots \ldots \ldots \ldots \ldots \ldots \ldots$

Sensory nucleus of the facial nerve $\ldots \ldots \ldots \ldots \ldots \ldots \ldots \ldots \ldots$

Motor nuclei of the facial nerre $\ldots \ldots \ldots \ldots \ldots \ldots \ldots \ldots \ldots$

Root fibers of the facial nerve $\ldots \ldots \ldots \ldots \ldots \ldots \ldots \ldots$

A dissertation submitted in partial fulfillment of the requirements for the degree of Doctor of Philosophy in the University of Michigan. 
Nuclear centers and root fibers of the cochlear nerve $\ldots \ldots \ldots \ldots \ldots \ldots 190$

Nuclear centers of the cochlear nerve ............... 190

Root fibers of the cochlear nerve .................. 194

Secondary connections of the cochlear centers $\ldots \ldots \ldots \ldots \ldots \ldots \ldots \ldots$

Vestibular nuclei and root fibers . . . . . . . . . . . . . . . . 197

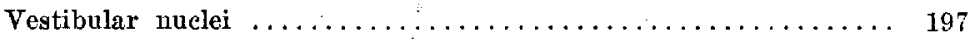

Vestibular root fibers $\ldots \ldots \ldots \ldots \ldots \ldots \ldots \ldots \ldots \ldots \ldots \ldots \ldots$

Secondary commections of the vestibular nerve $\ldots \ldots \ldots \ldots \ldots \ldots \ldots \ldots . \ldots 5$

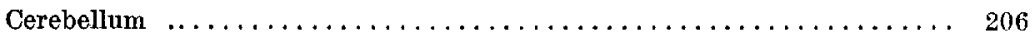

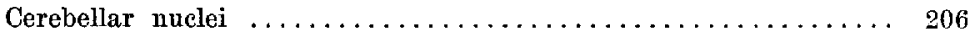

Fiber connections to the cerebellum ................ 208

Visceral sensory centers and connections of the glossopharyngeal,

vagus, and hypoglossal nerves $\ldots \ldots \ldots \ldots \ldots \ldots \ldots \ldots \ldots \ldots \ldots \ldots$

Efferent nuelei and root fibers of the glossopharyngeal, vagus, and hypoglossal nerves $\ldots \ldots \ldots \ldots \ldots \ldots \ldots \ldots \ldots \ldots \ldots \ldots \ldots \ldots \ldots . \ldots 11$

Efferent nucleus and root fibers of the glossopharyngeal . . . . , 211

Efferent nucleus and root fibers of the vagus $\ldots \ldots \ldots \ldots \ldots \ldots \ldots, 212$

Nucleus intermedius $\ldots \ldots \ldots \ldots \ldots \ldots \ldots \ldots \ldots \ldots \ldots \ldots \ldots$

Root fibers of the hypoglossal $\ldots \ldots \ldots \ldots \ldots \ldots \ldots \ldots \ldots \ldots \ldots$

The inferior olivary nucleus $\ldots \ldots \ldots \ldots \ldots \ldots \ldots \ldots \ldots \ldots \ldots \ldots \ldots \ldots$

Reticular nuclei $\ldots \ldots \ldots \ldots \ldots \ldots \ldots \ldots \ldots \ldots \ldots \ldots \ldots \ldots \ldots$

The posterior funicular nuclei $\ldots \ldots \ldots \ldots \ldots \ldots \ldots \ldots \ldots \ldots \ldots$

Summary and conclusions $\ldots \ldots \ldots \ldots \ldots \ldots \ldots \ldots \ldots \ldots \ldots$

\section{INTRODUCTION}

This account presents the results of a study of certain nuclear masses of the midbrain, cerebellar, and bulbar regions of the avian brain and the fiber connections of these masses. It may be regarded as a continuation of the work on the avian forebrain, thalamus, and tectum, recently published from this laboratory by Huber and Crosby ('29). The drawings and descriptive accounts in both contributions have been made from the same series.

The aim of the present contribution is to emphasize such relations and connections as show the corresponding development and interdependence of lower and higher centers. Particular attention is given to the regions of termination of the cranial nerves and to the secondary and tertiary connections of these areas with the thalamic, midbrain, and bulbar centers, and the relations of the cerebellum and particularly the cerebellar nuclei to reflex centers receive consideration. It is hoped in this way to contribute to the building up of our 
knowledge of the longitudinal conduction paths of the avian brain and to emphasize the synchronous development of the various parts.

The abundance of excellent material available for study was provided by Professor Huber. For this and the privilege of working in his laboratory and for his continued interest in the progress of the work I express hearty appreciation and thanks. I wish also to extend my sincere thanks to Dr. Elizabeth Crosby for her assistance and encouragement.

\section{MATERIAL AND METHODS}

The descriptions here given are based on forty-five series of avian brains, prepared by methods suitable for study of the cytoarchitectonic structure and fiber pattern. The series designed for study of the nuclear masses were prepared by fixation in a trichloracetic-mercury-alcohol solution, according to the method described by Huber ('27), and stained with toluidin blue. One series impregnated by the chrom-mercury method of Cox was available. Series prepared by the pyridin-silver and Weigert methods were used for study of the unmedullated and medullated tracts.

The cell material and the greater part of the pyridin-silver material were prepared by Prof. G. Carl Huber. The Weigert material was placed at our disposal. by Prof. Rollo McCotter. The material used in this study is the same as that listed by Huber and Crosby ('29) in their contribution on the avian diencephalon. The outlines and certain details of the lowpower figures were obtained with the projection apparatus and the drawings completed with the aid of the microscope. The camera lucida was employed in preparation of the highpower figures.

\section{LITERATURE}

The directly pertinent literature will be considered under the description of the proper fiber system or nuclear mass and need not be entered into in detail at this time. The fol- 
lowing account is intended as a general summary of the observations of workers in this field, with a brief statement of the methods employed and the results obtained by them.

The gross relations of the parts of the avian brain have been figured and deseribed by various workers. Partieular attention was devoted to this phase of the work by earlier observers, among whom may be mentioned Turner ('91), C. J. Herrick ('93), Susanne Phelps Gage ('95), Boyce and Warrington ('98), Kalischer ('01 and '05), Edinger, Wallenberg, and Holmes ('03), Edinger ('08), and others. Many of the later papers dealing with various parts of the avian brain contain figures illustrative of the gross structure, among which are the contributions by Ariëns Kappers ('20-'21), Hunter ('23), Craigie ('28), and Huber and Crosby ('29). The percentage weights of various parts of the brain in birds-including those of the optic tectum, cerebellum, and cerebral hemispheres-were computed by Lapieque and Girard ('06). Their computations appear to indicate, among other things, that the cerebellum varies in weight with the development of certain functional adaptations.

The embryologic development of the nuclear masses of the midbrain, cerebellum, and bulb in chicken was considered briefly by Mesdag ('09). A most interesting account of the development of the cranial nerves in this bird was given by Bok ('15), who built up, on the basis of his studies, his theory of stimulogenous fibrillation. The positions of the nuclei of the cranial nerves in birds with a consideration of their ontogenetic and phylogenetic development and migrations, together with a discussion of neurobiotaxis in relation to these facts, are given in the work of Ariëns Kappers ('08, '10, '12, '20-'21, '28) and his students (as, for example, Black, '22).

The eye-musele nerves, the oculomotor, trochlear, and abducens, are very well developed in birds, as is to be expected in animals with such large eyes. Their nuclei and the root fibers arising from them have received particular attention in the work of Ramón y Cajal ('09), Mesdag ('09), Ariëns Kappers ('12, '20-'21), and Craigie ('28). Mesdag, working on ehicken, identified the trochlear nucleus and figured the nuclear groups associated with the oculomotor nerve. In these groups he identified a nucleus dorsalis lateralis, a nucleus dorsalis intermedius, a nucleus dorsalis medialis, a nucleus ventralis, and a nucleus accessorius. He determined that the root fibers arising from the nucleus ventralis decussated to the other side of the brain immediately after their origin.

Ramón y Cajal ('09) studied particularly a small-celled group superior to the cephalic portion of the main nuclear mass of the oculomotor and homologous, in all probability, with the nucleus accessorius 
of Mesdag and others. He regarded it as the homologue of the Edinger-Westphal nucleus of mammals. In his embryonic chick material, of seven to nine days' ineubation, he demonstrated the presence and course of neuraxes from cells of this nucleus into the root fibers of the oculomotor nerve. Brandis ('95) was apparently the first to describe this group of cells, which he likewise regarded as comparable to the mammalian Edinger-Westphal nucleus. In his study of the motor nuclei of the cranial nerves of a series of vertebrates, Ariëns Kappers ('12, '20-'21) deseribed the oculomotor and trochlear cell groups in various birds. He subdivided the gray associated with the oculomotor into cell groups similar to those given by Mesdag, except that he apparently made no mention of the nucleus dorsalis intermedius of the latter observer. Ariëns Kappers, like Mesdag, found root fibers arising from the contralateral ventral nucleus. In his late paper on humming bird, Craigie ('28) deseribed the oculomotor nuclei. He found these strikingly large, but with nuclear subdivisions similar to those described by former workers. He noted a particular inerease in the ventromedial nucleus, from which arose root fibers which crossed to the opposite side at their level of origin.

The trochlear nucleus, according to certain observers (Ariëns Kappers, Craigie, and others), is in close approximation with the nuclei of the oculomotor and even overlaps their more caudal portions. This close interrelation is due to a secondary shifting of the nuclei, as the embryonic studies of Mesdag ('09) and Bok ('15) have indicated. No cellular differentiation within the trochlear nucleus has been observed (Ariëns Kappers, '20-'21).

The number of rootlets in the abducens nerve has been counted in the various birds (Black, '22; Craigie, '28). The results appear to indicate that the number is variable, since even in the same animal there may be a greater number of such rootlets on one side than on the other. Usually the fibers of the abducens pass out in front of the facial, as is the case in most mammals, and so form a true sixth nerve, but in other birds, for example, the cassowary, the greater part of the root fibers of the abducens leaves the brain stem behind the level of the facial nerve (Ariëns Kappers, '12). Likewise, Mesdag ('09) found part of the roots far caudalward in embryonic ehick material, and certain of the birds studied in the present account show similar relations of the root fibers of the abducens (p. 170). In birds the sixth nerve innervates the muscle of the nictitating membrane as well as the external rectus. In his study of the eranialnerve nuclei of various birds, Sinn ('13) deseribed and figured the nucleus and root fibers of the abducens nerve in the hawk. He found the nucleus irregularly oval in outline, relatively small, and con- 
nected by a demonstrable but relatively insignificant tract with the superior olive (the peduncle of the superior olive). In contrast to these results, Craigie (28) found the nucleus large and the root fibers of usual size in the humming bird. This latter observer likewise described an accessory nucleus of the abducens-an observation in accord with the work of various observers (Terni, '21; Preziuso, '24; and, according to Craigie, Addens, of the Central Institute for Brain Research at Amsterdam).

Rubaschkin ('03) studied the peripheral distribution of sensory trigeminal fibers in the olfactory mucous membrane. Brandis ('95) described the trigeminal and eye-musele nuclei in a series of birds. He found the incoming sensory trigeminal root breaking into ascending and descending branches and these terminating in the typical manner in relation to the chief sensory nucleus and the nucleus of the descending root of the trigeminus. The size of these two nuclei varied in the different birds, depending on the degree of development of the peripheral sensory fibers of the trigeminus. This writer also described fibers passing from the inner border of the sensory nucleus of the nerve across the midline to the cerebellar peduncle and the reticular gray of the opposite side. Those to the reticular gray appeared to course proximalward and formed, possibly, a central conduction path from this nucleus to higher centers. Connecting the chief sensory nucleus of the trigeminal with diencephalic and telencephalic centers is the path described by Wallenberg ('98, '03) as the isthmo-striatal and then as the quinto-frontal tract. This bundle arises from the sensory nucleus of the trigeminal, runs cephalad, is partly crossed at the level of the trochlear complex, and terminates in the thalamus, the ektostriatum, and the basal region of the forebrain in general (Wallenberg, '98, '03; Schroeder, '11; and for sparrow, Huber and Crosby, '29). Secondary ascending paths to the medial mesencephalic nucleus of the midbrain (nucleus mesencephalicus lateralis, pars ventralis of Ariëns Kappers, '21) have been described by Wallenberg ('04), Ariëns Kappers ('21), and others. Sinn ('13) found the sensory nucleus of the trigeminal enormously developed in certain birds, the crossed root fibers well developed, and the descending root similar to that of mammals. van Valkenberg ('11 a) and Ariëns Kappers ('20-'21) pointed out that the more cephalic root fibers of the trigeminal (that is, the mandibular branch) are dorsal in the descending trigeminal root to the more caudally entering fibers of the ophthalmic. The mandibular fibers terminate at the level of the glossopharyngeal and vagus nuclei, the ophthalmic extend to the cord. A review of the positions, relations, and major connections of the sensory trigeminal nuclei of birds is to be found in the Ariëns Kappers' text ('20-'21). The literature 
on the mesencephalic root of the trigeminal nerve, with a description of its course and cells of origin in various vertebrates, including bird, is to be found in the recent paper by Weinberg ('28). (See also van Valkenberg, '11 a.) His account for bird is based on the same series as were used for the present paper. According to Craigie ('28), the sensory trigeminal nuclei exhibit some special differentiation in humming bird, for in this bird there is, in addition to a dorsal sensory nucleus and nucleus of the descending spinal root, a 'frontal nucleus' of the trigeminal nerve, which is an enlargement of the cephalic end of the nucleus of the deseending root. The chief sensory nucleus of mammals is homologous with both the frontal and dorsal trigeminal nuclei (Craigie). As efferent connections he described a trigemino-cerebellar tract previously seen in chicken by Biondi ('13, quoted from Craigie, '28) and the quinto-frontal path of Wallenberg ('03). The dorsal position of the dorsal trigeminal nucleus he regarded as due to the neurobiotaxic influence of the vestibular centers.

According to Sinn ('13), the motor trigeminal root has two nuclei, a chief nucleus comparable to that of mammals and a second nucleus which is situated close to the dorsal nucleus of the facial nerve. Ariëns Kappers ('12, '20, '21) likewise differentiated two motor trigeminal nuclei in birds, a smaller medial one, the root fibers of which arched dorsalward and then lateralward, and a larger lateral one; the root fibers of which passed directly ventrolateralward to the surface of the brain. According to Craigie ('28), in the motor trigeminal nucleus of the humming bird there is a dorsal nucleus, a ventrolateral one, further divisible into lateral, dorsomedial, and ventromedial portions, and, in certain specimens, some indications of a third group of motor cells. Other descriptions of the motor trigeminal nueleus are to be found in the work of various observers (Brandis, '95 ; Edinger, '08; Ariëns Kappers, '20-'21, and others).

Brandis ('94) demonstrated the presenee in birds of a single motor nucleus of the facial nerve. Later work (Ariëns Kappers, '08, '10) appears to indicate that a second motor facial center is present in at least certain of the birds studied by Brandis. For chicken, Kosaka and Hiraiwa ('05) deseribed a dorsal or digastric nucleus, with an associated 'Nebenkern,' and a ventral or chief motor nucleus for the facial nerve. Two groups were recognized by Ariëns Kappers ('10) in quite a number of birds, such as Ciconia and Chrycomitris, for example, but he was able to demonstrate only a single group in Casuaris. The latter observer was the first to analyze carefully this nuclear group in avian forms. The two major groups of the motor facial described by previous observers were identified by Black ('22) for Cacatua. He regarded the 'Nebenkern' of the Kosaka and 
Hiraiwa account as represented by the candoventral extension of the dorsal motor nucleus of Cacatua. There is considerable variation in the size and relative position of these nuclei in the various avian forms. Thus in quite a number of birds (including Columba, Ciconia, and Cacatua) the nuclei lie in front of the outgoing motor root, while in Casuaris, at least, the nuclei and root fibers are found in the same plane.

Among the observers who have given particular attention to the vestibular and cochlear nuclei and secondary connections are Wallenberg ('98 and '00), Holmes ('03), Ramón y Cajal ('08), Schepman ('18, quoted from Ariëns Kappers), and Ariëns Kappers ('20-21). Wallenberg ('98) gave an account of the secondary paths following destruction of the cochlear nucleus magnocellularis and of certain vestibular areas. He described the course of the major secondary cochlear path (lateral lemniscus) as running cephalad for a short distance after its origin in nucleus magnocellularis, turning medialward, decussating, and at the level of nucleus isthmo-opticus (nucleus isthmi of Wallenberg; see alsi Craigie, '28, and Huber and Crosby, '29) coming into relation with the nucleus of the lateral lemniscus, and terminating in the central and medial region of the nucleus mesencephalicus lateralis (pars dorsalis of Ariëns Kappers or the mammalian inferior colliculus). From the above account it is evident that Wallenberg had identified the avian trapezoid body-an identification which has been confirmed by Holme: ('03), Ramón y Cajal ('08), and others. Ramón y Cajal believed that the tract arose from neurons of the nucleus laminaris-a statement with which the present account is in agreement. In his 1900 paper Wallenberg summarized the vestibular connections. Holmes ('03), in his study of the comparative anatomy of the acoustic nerve, gave a resumé of the nuclei of termination of this nerve and their secondary connections. The work was based on young and adult pigeons. The results, in general, agreed with those of Wallenberg. Holmes, like Wallenberg, was unable to trace any direct fibers of the cochlear nerve into nucleus laminaris, and came to the conclusion that laminaris was a specially differentiated vestibular center. The most detailed and complete description of the nuclei of termination of the acoustic root fibers and the fiber relations of these nuelei to higher centers is to be found in the contributions of Ramón y Cajal ('08). By use of silver impregnation methods he was able to recognize the synaptic relations of root fibers to the nuclei and to determine the origin and direction of conduction of many of the paths. The work of this observer and that of Wallenberg (' 98, , 00$)$ are referred to in detail in the deseription of these centers in the present paper and will not receive further attention at this time. In addition to those mentioned above, accounts 
of the acoustie centers in avian forms are to be found in the work of Brandis ('94), Schepman ('18, quoted from Ariëns Kappers), and Ariëns Kappers ('20-'21).

Brandis ('94), Ariëns Kappers ('11, '20-'21), Black ('22), and others have done quite extensive work on the relations and positions of the cells of origin of the glossopharyngeal, vagus, and accessory cell columns in birds. An understanding of these is dependent upon an understanding of the hypoglossal. The somatic motor column of the spinal cord is represented cephalad as a dorsal and a ventral column. The ventral column is directly continuous with the ventral horn column of the spinal cord and is regarded by certain observers (Ariëns Kappers, '12, and Black, '22) as hypoglossal and by others (Kosaka and Yagita, '03) as containing no true hypoglossal neurons. The more dorsal group extends forward and comes into relatively close relationship with neurons of the vagus. According to Black ('22), nucleus intermedius in certain birds contains both vagal and hypoglossal components; in other birds it may be entirely vagal, and in still others strietly hypoglossal in (haracter. Brandis ('93) and Ariëns Kappers ('12) also favored the presence of neurons of both vagus and hypoglossal nerves in nucleus intermedius, at least in certain birds. The dorsal motor nuclear column of the glossopharyngeus and vagus appears to be continuous in most birds (Brandis, '93; Ariëns Kappers, '12; Black, '22; Craigie, '28, and others). A ventrolateral vagus nucleus was described by Ariëns Kappers ('12), Black ('22), and others and a ventral glossopharyngeal was identified in humming bird by Craigie ('28) and apparently in other avian forms by $\Lambda$ ddens (Craigie, '28, pp. 430-431). The relations of the accessory nerve do not appear to be entirely clear (Black, '22). The number of taste fibers in birds is relatively small, yet the fasciculus solitarius is relatively highly developed. Ramón y Cajal described and figured two uncrossed faseicles (fascienlo solitario dorsal or interno, fasciculo solitario antero-externo) and a crossed bundle (fasciculo solitario antero-interno). However, the size of the fasciculus solitarius in bird is associated with the development of general visceral rather than gustatory sensibility. However, some fibers from VIIth, IXth, and Xth nerves leave the fasciculus solitarius and turn dorsalward to end in either the dorsolateral bulbar nucleus or the dorsomedial bulbar nucleus. These relatively small components of seven, nine, and ten are presumably the taste fibers. In humming bird Craigie ('28) described a relatively large sensory root of the facial.

Various subdivisions of the cerebellum are to be found in the accounts presented by the earlier workers, Turner ('91), Friedländer ('98), and others. A review of this earlier literature is to be found 
in Ingvar's ('18) paper and need not receive attention here. Several attempts at homologizing avian cerebellar regions with mammalian areas were made by these early observers, with somewhat contradictory results. They were not in agreement as to whether or not the cerebellar hemispheres are present in avian forms. Certain observers were inclined to regard the cerebellum of bird as representative only of the vermis portion of mammals. Others, as Jelgersma (' 89 , quoted from Brouwer) and Ramón y Cajal ('08), thought that more or less rudimentary hemispheres might be present.

An account of the embryonic development of the cerebellum with divisions into three lobes (anterior, dorsal, and posterior) is to be found in the work of Murphy ('00, quoted from Ingvar, '18; paper not available). Brower ('13) also studied the embryonic development of the region. He discussed the appearance of fissures, none of which were present in his or Murphy's nine-day material. By means of reference to the literature, he likewise reviewed the status of cerebellar localization. For further details the original paper should be consulted, since its subject matter is largely outside the scope of the present paper.

The nuclei of the cerebellum and their connections have been most thoroughly described by Ramón y Cajal ('08 a). He identified a ganglion of the roof, a semilunar nuclear group, an intercalate group, and an inferior and a superior lateral nuclear field. A brief account of the region in humming bird is to be found in the paper by Craigie ('28).

The inferior olive has been described for birds by Williams ('08), Yoshimura ('10), and Kooy ('16). According to these observers, it is clearly differentiated in avian forms and consists of a dorsal and a ventral lamella. Yoshimura was inelined to distinguish between the inferior olive of runners, which has a less well-developed ventral portion, and that of other birds. Kooy interpreted these differences as representative of the extremes of a single developmental series. Runners belong to the more primitive birds, and consequently the inferior olive of this group probably represents a more primitive olive. The details of lamellar arrangement and cytologic structure (which varies somewhat in different birds and with the size of birds) will be considered later.

The reticular nuclei have been discussed particularly by Ramón y Cajal ('09), van Hoevell ('11), and Ariëns Kappers ('20-21). In general, four groups have been recognized: a nucleus reticularis inferior at the level of the vagus, a nucleus reticularis medius at the level of the facial, a nucleus reticularis superior in the plane of the upper trigeminal centers, and a substantia reticularis mesencephali, which includes nucleus ruber and the interstitial cells of Ramón y Cajal. 
The question of ascending systems to higher centers other than lateral lemniseus and secondary trigeminal paths has considerable interest for both the comparative neurologist and the physiologist, since its demonstration would determine the homologies of certain diencephalic centers and give at the same time a eue to their physiologic functions. The avian homologues of the mammalian nucleus of the posterior funiculi have been identified by various observers, but have been most completely described by Zeehandelaar ('21), who identified nucleus gracilis and nucleus cuneatus (nuclei of Goll and Burdach) and found the medial nucleus ('Schwanzkern') present in certain birds and lacking in others. The nucleus of Blumenau he found to be absent in most eases. The problem of actually tracing forward crossed fibers from these centers to diencephalic areas is a diffienlt one when attempted with normal preparations, and although suggestions of the probable presence of the path are to be found in the literature (Ariëns Kappers, '20-'21), a complete unquestionable demonstration of its presence in normal preparations from origin to termination has not been given. However, it appears to have been demonstrated by Wallenberg in degeneration preparations. This latter observer found that injuries to the posterior funicular nuclei, or at least to nuclear masses in that neighborhood, led to the degencration of a path which after decussation ran forward near the ventromedial surface of the bulb and which terminated in part in various bulbar and midbrain centers and in part reached the ventral part of the thalamus (the nucleus intercalatus and the medial capsule of the red nucleus). In part it terminated in hypothalamic centers of the same and opposite sides. Wallenberg himself suggested that the medial and lateral parts of the bundle are homologous, respectively, with the medial lemniscus and the mammillary peduncle of mammals.

\section{DESCRIPTTON OF NUCLEAR MASSES AND FIBER PATHS}

Nuclei and root fibers of the eye-muscle nerves

The relations existing betwoen the size of the eves and eye musculature and the development of the central nuclei supplying this musculature are very apparent in the large motor nuclei supplying correspondingly large eye muscles in birds. More than twenty years ago, Edinger ('08) emphasized the point that this was a relationship which apparently existed throughout the vertebrate series when he pointed ont that the sphincter palpebrarum of the whale was as large as 
the human gluteus maximus and that it was associated with a correspondingly increased oculomotor nuclear group which extended into the thalamus.

Oculomotor nuclei and root fibers. The neurone groups forming the nucleus of the oculomotor nerve have been described and named by Mesdag ('09), Ramón y Cajal ('09), Ariëns Kappers ('20-'21), Black ('22), Craigic ('28), and others. In the avian brains here studied the subdivisions of the nuclear mass are essentially those of the preceding workers. Thus, a dorsolateral, a dorsomedial, a ventromedial, and an accessory, the Edinger-Westphal nucleus, have been recognized. The relative extent of these groups varies apparently in different birds. Thus, the anterior limit of each of the avian groups considered in the present account differs from that set by Ariëns Kappers ('12) for penguin and by Craigie ('28) for humming bird. Both of these observers found that the dorsolateral and the Edinger-Westphal nuclei extended the farthest cephalad. The material available on sparrow, dove, duck, and parrakeet indicates that the most anterior portion of the oculomotor nucleus is occupied by the ventromedial group. The limits here set not only for this latter group, but for the other nuclear groups of the oculomotor as well, are comparable in general with those figured by Black ('22) in his reconstruction of the motor centers of Cacatua. In chicken, the ventromedial group disappears cephalically at a plane slightly in front of that occupicd by the more frontal portions of the three other nuclear masses of the oculomotor.

At its cephalic end the ventromedial nucleus (fig. 1, B) of sparrow is between the red nuclei and slightly dorsal to them. It increases lateralward, tending to surround the ventral border of the medial longitudinal fasciculus. A little farther caudalward it becomes more spherical, and then, though decreasing gradually in size, occupies the same position to its posterior limit. It does not extend as far caudalward as does the dorsomedial group. The dorsomedial nucleus (fig. 1, B) makes its cephalic appearance just a fow sections caudal to 
the anterior limit of the ventromedial nucleus. In crosssection it has a longer dorsoventral than transverse extent and is more or less continuous with both the dorsolateral and the Edinger-Westphal nuclei. It extends farther caudalward than the ventromedial portion. Both the ventromedial and the ventrolateral portions are replaced caudally by cells of the median raphé. The neurons constituting the dorsomedial nucleus are relatively large, multipolar cells, very similar to those found in the ventromedial nucleus. The dorsolateral nucleus (fig. 1, B) makes its appearance a little farther caudalward than does either of the medial groups. The nucleus increases in size and forms a spherical mass lateral to the medial longitudinal fasciculus and ventrolateral to the Edinger-Westphal nucleus after the appearance of the latter. The dorsolateral group, when once fully established, runs caudalward without change of shape or position into the anterior end of the nucleus of the trochlear nerve. Its cells are slightly larger than the cells of the other nuclear groups of the oculomotor. The Edinger-Westphal nuclens of the oculomotor (fig. 1, B) lies immediately under the ventricle and dorsal to the dorsomedial and dorsolateral nuclei of the nerve. It is the shortest nucleus of the group, for it begins behind the cephalic poles of the other oculomotor nuclei and terminates in front of their caudal ends. Its cells are smaller and more densely packed than are those of the other motor nuclei of the nerve. It has, on the whole, the appearance of a general visceral efferent or preganglionic center. The neuron groups of the oculomotor nucleus as just described in sparrow may be very definitely delimited from one another, and the same is true in duck, dove, and parrakeet. In chicken (fig. 1, A), the groups may be named and defined as above, but are much more continuous with one another. The dorsomedial nucleus throughout most of its extent is continuous by a relatively wide cell column with the ventromedial nueleus and is partially continuous with the dorsolateral nuclens. 
Root fibers of the oculomotor nerve arise from each of the four oculomotor neuron groups. They emerge from the medial surfaces of the Edinger-Westphal and dorsolateral nuclear groups and turn medioventralward into the large nerve root of the same side. Homolateral fibers, running largely lateral to the ventromedial group, join them from the ventromedial nucleus. The ventromedial nucleus, as has been found for other birds (Mesdag, '09; Craigie, '28), gives rise to erossing fibers. Whether or not they are all crossed it has
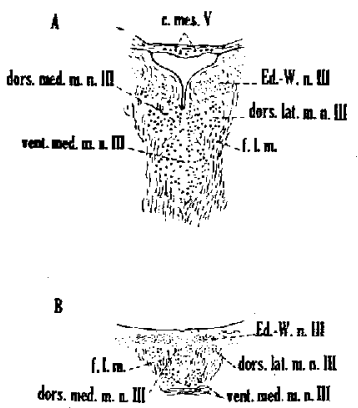

Fig. 1 A. Cross-section of chicken brain at level of nuelei of oculomotor nerve. Toluidin-blue preparation. $\times 7.5$. B. Cross-section of sparrow brain at level of nuclei of oculomotor nerve. Toluidin-blue preparation. $\times 7.5$. c.mes.F, cells of mesencephalie root of trigeninal nerve; dors.lat.m.n.III, dorsolateral motor nucleus of oculomotor nerve; dors.med.m.n.III, dorsomedial motor nulleus of oeulomotor nerve; $E d .-W, n . I I I$, Edinger-Westphal nueleus of oeulomotor nerve; f.l.m., fasciculus longitudinalis medialis; vent.med.m.n.III, ventromedial motor nucleus of oculomotor nerve.

not been possible to determine. The root fibers run almost directly ventralward on each side of the midline and leave the mesencephalon on its ventromedial surface considerably in front of the plane of its nuclear groups.

Trochlear nucleus and root fibers. The cephalic end of the nucleus of the trochlear nerve cannot be delimited from the caudal end of the dorsolateral nucleus of the oculomotor nerve, particularly since the cell type is the same in the two nuclei. The trochlear nucleus lies just under the ventricle and on the dorsolateral edge of the medial longitudinal fas- 
ciculus. It extends caudalward to abont the cephalic limit of the ventral nucleus of the motor trigeminal nerve. The nucleus and root fibers of the trochlear are shown in the Huber and Crosby paper ('29) and do not require further illustration here.

Direct root fibers of the trochlear nerve emerge from the dorsolateral border of the posterior half of the nucleus, run lateralward into the anterior medullary velum, in which they decussate (fig. 2).

Abducens muclei and root fibers. The major nucleus of the abducens nerve occupies a position at the side of the median raphé, slightly dorsal to a transverse midplane section (figs. 4 to 7 ). It appears caudally in a plane passing through the motor root of the facial and through the vestibular nuclei. It increases in size immediately and eontinues, with slight change in shape or position, to the candal limit of the ventral motor nucleus of the trigeminal nerve.

An accessory nucleus of the abducens was described by Terni ('21), Preziuso ('24), and Craigie ('28). According to this last observer, the nucleus has also been seen by Addens, whose results as yet are unpublished. This nucleus (figs. 5 and 7 ) has been identified in the sparrow material available. In this bird it appears cephalically at a crosssectional level through the middle of the major abducens nucleus and in a field containing the dorsal and ventral motor nuclei of the facial nerve. It is situated lateral to the superior olive at certain planes, but behind the level of this latter nucleus it continues caudalward in approximately the same general position until it becomes continuous at its caudal end with the ventral part of the nucleus of the descending root of the trigeminal. The cells of the accessory nucleus of the abducens are slightly larger than those of the major nucleus of this nerve. The nucleus has been identified in the dove, parrakeet, duck, and chicken material, but in these series is not so readily delimited from other large cells of the region as in the sparrow sections. 
In none of the material at present available has it been possible to demonstrate root fibers to the accessory nucleus of the abducens. The abducens root, however, is relatively large in sparrow (figs. 4 to 7 ). Consequently, bundles of this nerve are found throughout the region extending from a

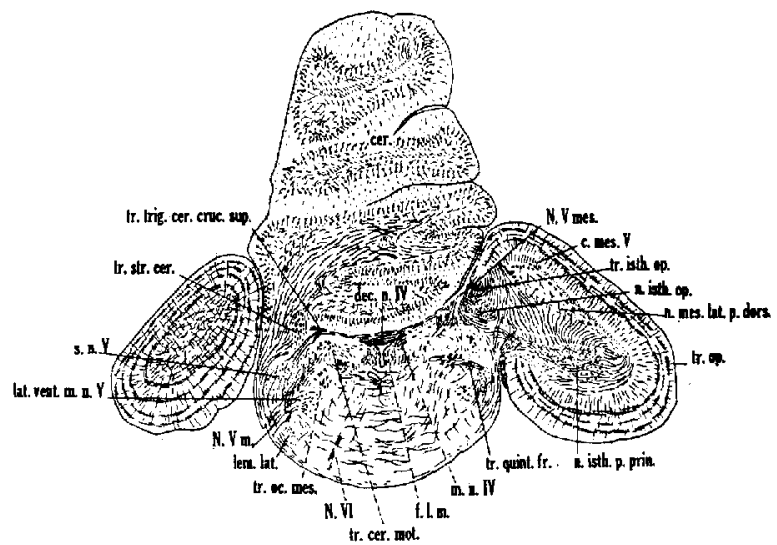

Fig. 2 Cross-section through brain of sparrow at level of decussation of abdueens nerve. Pyridin-silver preparation, $\times 7.5$. cer., cerebellum; c.mes. $F$, cells of mesenecphalic root of trigeminal nerve; decn.IV, decussation of trochlear nerve; f.l.m., fasciculus longitudiualis medialis; lat.vent.m.n. $V$, lateroventral motor nueleus of the trigeminal nerve; lem.lat, lateral lemniseus; m.n.IV, motor mudeus of trochled nerve; m.n.VI, motor nucleus of abdueens nerve; n.tsth.opt., nucleus isthmo-opticus; n.isth.p.prin., nucleus isthmi, pars prineipalis; n.mes.lat. p.dors., nueleus mesencephalieus lateralis, pars dorsalis; $N . V I$, abducens nerve; $N . V m$. motor trigeminal nerve; $N . V$ mes., mesencephalic root of trigeminal nerve; s.n.V, chief sensory nucleus of trigeminal nerve; tr.cer.mot., tractus cerebellomotorius; tristh.op., tractus isthmo-opticus; trocmes., tractus oceipito-mesencephalicus; tr.op., tractus opticus ; tr.quint.f $r$. tractus quinto-frontalis; tr.str.cer., tractus strio-cerebellaris; tr.trig.cer.eruc.sup., tractus trigemino-cerebellaris crueiatus superior.

plane through the cephalic limit of the trigeminal fibers to a plane behind the caudal limit of the root fibers of the facial. Thus, certain bundles of the abducens or sixth nerve leave the ventral surface behind the most caudal bundles of the facial or seventh nerve. This condition has been found to obtain in certain other birds. The individual fascicles of the abducens root follow the usual course; that is, they run 
ventral and slightly lateral from the major nucleus of the nerve to the ventral surface of the medulla oblongata.

\section{Fiber connections of the eye-muscle nuclei}

The following brief summary makes mention of such connections of the eye-muscle nuclei as it was possible to demonstrate in the material available. Many of these connections have been demonstrated in various avian forms, others of them are relatively less well known. The connections of the oculomotor group will be considered first.

Fibers from the nucleus mesencephalicus lateralis, pars dorsalis (the inferior colliculus of mammals), from the pretectal and subpretectal nuclei, and from the optic tectal region as well (which run here with the tectobulbars), stream loosely across the dorsal border of the mesencephalon and enter the lateral surfaces of the Edinger-Westphal and dorsolateral oculomotor nuclei. Certain bundles swing dorsally around the Edinger-Westphal nucleus, turn ventralward along the midline, and make connections with the dorsomedial, dorsolateral, and ventromedial groups along their medial surfaces. Toward the caudal end of the nuclear complex of the oculomotor, the tectal fibers are joined in their course by fibers from the ventromedial border of the nucleus isthmo-opticus and by additional bundles from the more ventral portions of the superior collicular region. These bundles just described may reach all the nuclear groups of the oculomotor, but they distribute principally to the Edinger-Westphal nucleus and to the nucleus of the trochlear nerve. The tectal fibers enter the trochlear nucleus on its dorsal surface.

Further connections with optic centers are to be found in the tract between the nucleus ectomamillaris and the oculomotor centers. This tract was described by Beccari ('23) for Varanus and by Huber and Crosby ('26 and '29) for alligator, sparrow, and dove. Tractus infundibuli of Jelgersma ('96) reaches the region of the oculomotor nucleus, although it has not been possible in the present material to follow it into the nucleus. Crossed fibers of the posterior commissure in 

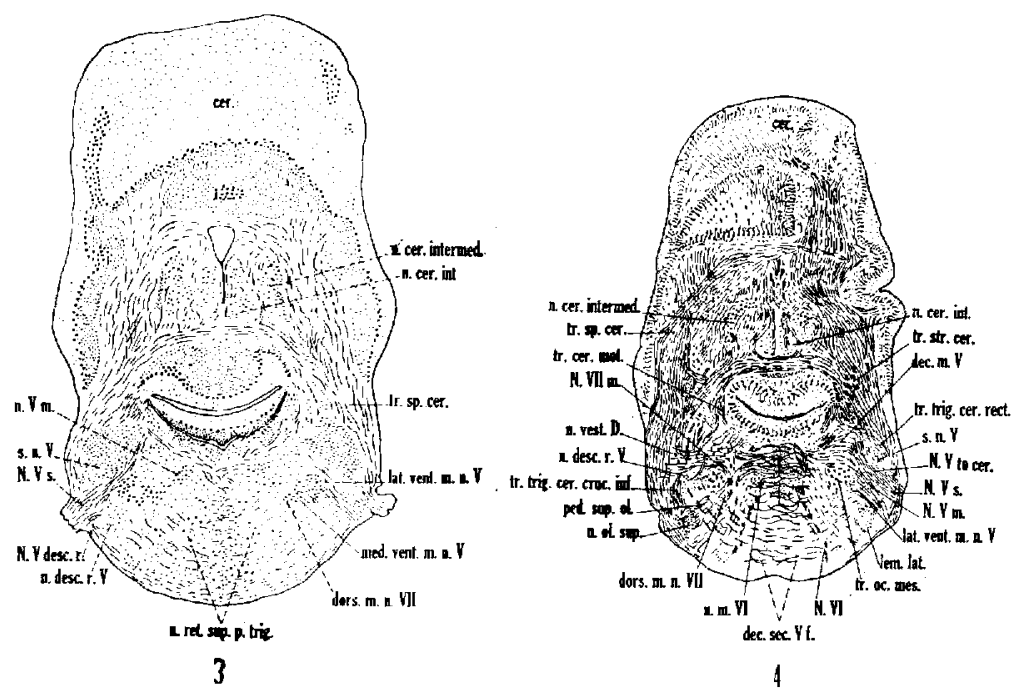

Fig. 3 Cross-section through the l,rain of sparrow at the level of the nuelei of the trigeminal nerve. Toluidin-blue preparation, $\times 7.5$. cer., cerebellum; dors.m.n.VII, dorsomedial motor nuleus of facial nerve; lat.vent.m.n.V, lateroventral motor nucleus of trigominal nerve; med.vent.m.n.V, medioventral motor nucleus of trigeminal nerve; nocrintrmed., nucleus cerebellaris intermedius; n.cer.int., nucleus cerebellaris internus; n.desc.r. $F$, nucleus of descending root of trigeminal nerve; N.descr.V, desecuding root of trigeminal nerve; n.ret.sup. p.trig., nucleus reticularis suporior (trigeminal portion); n. $F$ m., dorsal motor nucleus of trigeminal uerve; $N . V s$, sensory trigeminal nerve; s.n.V, chief sensory nucleus of the trigeminal nerve; tr.sp.cer, tractus spino-cerebellaris.

Fig. 4 Cross-section through the nuelei and root fibers of the trigeminal nerve. Jyridin-silver preparation. $\times 7.5$. dec.m.V, decussuting molor trigeminal fibers; deesee. $F f$, decussating secondary trigeminal fibers; dorm.n.FII, dorsal motor nucleus of facial nerve; lem.lat., lemniscus lateralis; lat.men.m.n.F, lateroventral motor nucleus of trigeminal nerve; n.cerint, oucleus corebellaris internus; n.cer. intermed., nucleus cerebellaris intermedius; n.leser. $V$, molens of descending root of trigeminal nerve; n.m.VI, motor nueleus of ahducens norve; n.ol.sup., nucleus olivarius superior; n.vest.l), nucleus vestibularis ventralateralis (Deiters); $\boldsymbol{N} . \boldsymbol{V} \boldsymbol{m}$, motor trigeminal nerve; $N . V$ s., sensory trigeminal nerve; $N . V$ to cer., direct trigeminal to cerebeltum; $N . V I$, abdueens nerve; $N . V I I m$. motor facial nerve; ped.sup.ot., peluncle of superior olivary nucleus; s.n.V, chief sensory nucleus of trigeminal nerve; trecr.mot, tractus cerelsellomotorius; troomes., tractus occipito-mesencephalicus; tropnin-cer, tractus spino-cerebellaris; tr.sp.eervent, tractus spino-cerebellaris ventralis; tr.strecr., tralus strio-cerebellaris; tr.trig.

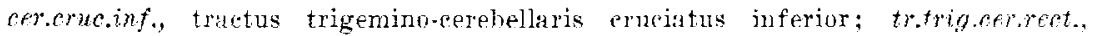
tractus trigemino-cerebellaris rectus. 
their course toward the medial longitudinal fasciculus contribute fibers to the dorsomedial oculomotor and perhaps to the dorsolateral oculomotor mueleus as well. The medial longitudinal fasciculus makes obvious connections with the nuclei of the oculomotor, trochlear, and abducens nerves, as is the case in vertebrates in general.

The most lateral of the cerebello-motorius bundles swing's medialward, ventral to quadrangularis, and makes quite definite connections with the major nucleus of the abducens. The most internal or medial bundles run forward to the trochlear nucleus of the opposite side, having decussated in the region immediately below the rentricle. Some of them extend to at least the caudal part of the oculomotor nuclear group. In their course forward these fibers appear to contribute scattered homolateral bundles to the major abducens nuclens. Fine, apparently unmedullated fibers can be followed from the superior olivary nucleus to the main nucleus of the abducens nerve. This bundle, which is the homolog'ue of the mammalian peduncle of the superior olive, has a position just lateral to the root fibers of the abducens nerve. It is a very definite bundle at levels where the trapezoid fibers swing downward from nucleus laminaris.

\section{Tectobulbar tracts}

These fiber systems are very well developed in avian forms, as is to be expected where the optic tectum is so large. They have been identified as a whole or in part by various observers (Edinger, Wallenberg, and Holmes, '03; Ariëns Kappers, '20-'21; Craigie, '28; Papez, '29, and others). They have been studied also in degeneration material by Münzer and Wiener ('98) and by Fdinger, Wallenberg, and Holmes ('03). Normal material is not the most favorable for the tracing of these paths, since they cannot be separated from other similarly running bundles once they have turned caudalward. Münzer and Wiener traced an uncrossed tectobulbar path in birds to a gray nuclear mass which they considered the homologue of the gray associated with the mammalian trapezoid 


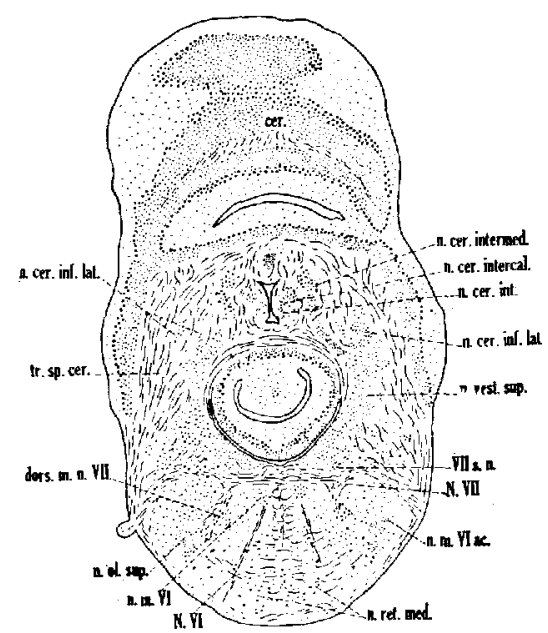

5

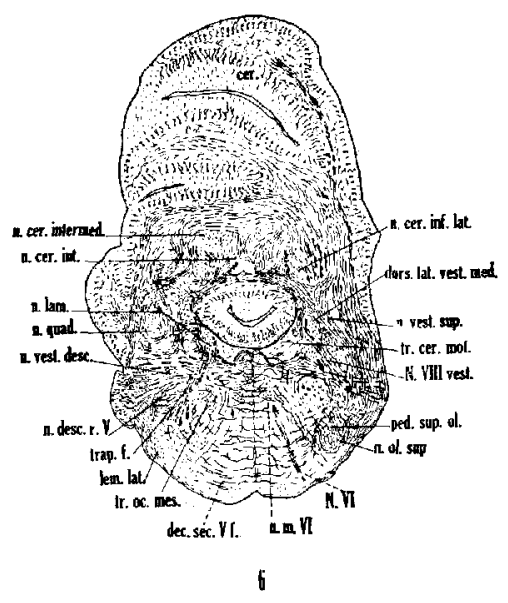

Fig. 5 Cross-section through the cerebellar nuclei and the nuclei of the abducens and facial nerves of the sparrow. Toluidin-blue preparation. $\times 7.5$. dors.m.n.FII, dorsal motor nucleus of facial nerve; n.eer.inf.lat., nucleus cerebellaris inferioris lateralis; n.cer.intereal., nueleus cerebellaris intercalatus; n.cer. int., nucleus cerebellaris internus; n.cer.intermed., nueleus cerebellaris intermedius; n.m.VIac., accessory motor nueleus of abducens nerve; n.m.VI, chief motor nucleus of abdueens nerve; n.ol.sup., nucleus olivarius superior; n.ret.med., nucleus reticularis medius; n.vest.sup., nucleus restibularis superior; N.VI, abducens nerve; $N . V I I$, facial nerve; tr.sp.cer., tractus spino-cerebellaris ; VII s.n., visceral sensory nucleus of facial nerve.

Fig. 6 Cross-section through the brain of the sparrow at the level of the centers of the cochlear and restibular nerves. Pyridin-silver preparation. $\times 7.5$. dee.see. $\mathrm{f}$, decussating secondary trigeminal fibers; dorslat.vest.med, dorsolateral vestibular nuclear group, medial division; lem.lat., lcmniseus lateralis; n.cer.inf.lat., nucleus cerebellaris inferior lateralis; n.cerintermed., nucleus cerebellaris inferior intermedius; n.cerint, nucleus cerebellaris internus; n.desc. $r . V$, nucleus of descending ront of trigeminal nerve; n.lam., nucleus laminaris; n.m.VI, chief motor nucleus of abducens nerve; N.VI, motor abducens nerve; n.olsup., nucleus olivarius superior; n.quad., nucleus quadrangularis; n.vest.dese., nucleus vestibularis descendens (inferior); n.vest.sup., nueleus vestibularis superior; N.VI, abducens nerve; N.VIII vest., restibular nerve; ped.sup.ol., peduncle of superior olivary nueleus; tr.cer.mot., tractus cerebello-motorius; troc.mes., tractus occipito-mesencephalicus; trap.f., trapezoid fibers. 
body. Edinger and Wallenberg carried this bundle to the lateral division of a similar gray mass in the bulb and in part back to the cervical cord. These bundles are obviously the ventral tectospinal paths which have been described by Ariëns Kappers and apparently by Craigie ('28), although the path so labeled by this latter observer appears to be the ventral part of the dorsal tectobulbar path. A crossed dorsal tectobulbar system was demonstrated by Edinger, Wallenborg, and Holmes ('03) after destruction of the optic lobes in bird. They obtained a degeneration of this path in nine experiments and were able to follow it through the bulbar regions and into the anterior ground bundle of the cord. The silver-impregnation material makes very easy the identification of these tracts at their origin. It is possible to trace them across the field until they turn eaudalward, but then the very richness of the impregnation makes it impossible to distinguish them from other Iongitudinally running bundles in the region. The following is a brief summary of these paths in so far as they have been followed in the material now available. The account is based on sparrow, but the relations are essentially the same in dove.

Dorsal tectobulbar tract. The dorsal tectobulbar tract on leaving the tectum swings ventral to the nucleus mesencephalicus lateralis, pars dorsalis, then runs dorsomedialward to the midline where it crosses ventral to the medial longitudinal fasciculi. In its course it interdigitates with the root fibers of the oculomotor nerve, while its more posterior fibers cross the ventral part of the cephalic end of the oculomotor nucleus. The crossed fibers accumulate in a bundle ventrolateral to the medial longitudinal fasciculus. They appear to be joined by uncrossed fibers from the more caudal part of the tectobulbar system, although this latter point needs substantiation through experimental work. An uncrossed dorsal tectobulbar path was described by Ariëns Kappers ('20-'21). Craigie ('28) found only crossed fibers in humming bird. The bundle thus formed runs caudalward, probably to motor and reticular centers of the bulb, but its further course has not been determined. 
Ventral tectobulbar tract. The ventral tectobulbar tract is farther caudal than is the dorsal bundle. From the tectal regions it swings ventromedialward. Some of its fibers appear to cross in the midline close to the ventral surface (Ariëns Kappers, '20-'21). It is uncertain whether these are

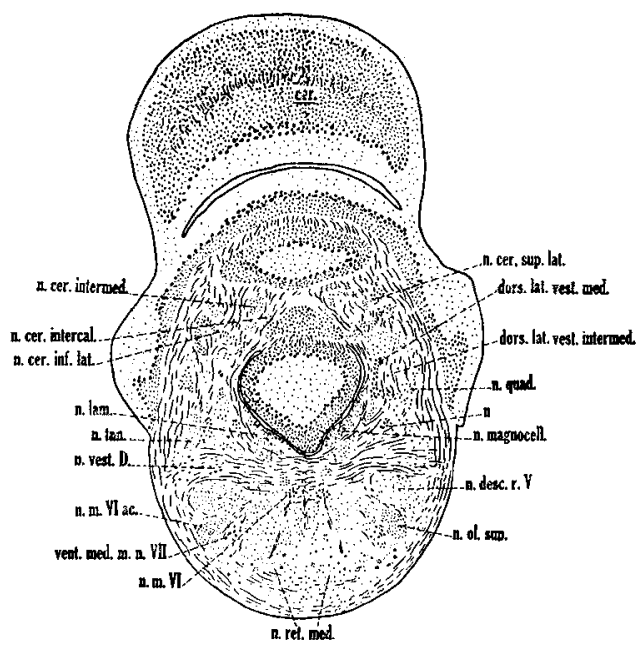

Fig. 7 Cross-section through the brain of the sparrow at the level of cerebellar and vestibular nuelei. Toluidin-blue preparation. $\times 7.5$. dors.lat.vest.med., dorsolateral vestibular nuclear group, pars medialis; $n$., nucleus vestibulocerebellosus of Cajal (dorsolateral vestibular nucleus group, pars lateralis); n.cer. inf.lat., nueleus cerebellaris inferior lateralis; nocer.intereal., nucleus eerebellar is intercalatus; n.cer.intermed., nucleus cerebellaris intermedius; n.cer.sup.lat., nucleus cerebellaris superior lateralis; n.desc.r.V, nucleus of the descending root of the trigeminal nerve; n.lam., nueleus laminaris; n.magnocell., nueleus magnocellularis; n.m.VIac., accessory motor nucleus of the abducens nerve; n.m.VI, chief motor nueleus of the abducens nerve; nol.sup., nueleus olivarius superior; n.ret.med., nucleus reticularis medius; n.quad., nucleus quadrangularis; n.tang., nucleus tangentialis; n.vest.D., nucleus vestibularis ventrolateralis (Deiters); vent.med.m.n.VII, ventromedial motor nucleus of the facial nerve.

the crossed fibers described by Craigie. They do not appear to correspond to the bundle so labeled in his figure 14 . The majority of the bundles accumulate in the ventrolateral part of the midbrain and run caudalward. Their termination is probably in efferent centers of the bulb and possibly of the cord as well. 


\section{Trigeminal nuclei and root fibers}

The trigeminal complex is highly developed in the avian material at hand, and its secondary connections not only with reflex centers of the bulb and cerebellum, but also with tectal, thalamic, and forebrain areas indicate that it plays an important rôle in avian physiology. van Valkenberg ('11 a), Ariëns Kappers ('20-'21), Craigie ('28), Papez ('29), and others described and figured the chief sensory nucleus and the nucleus of the descending trigeminal root in various birds. van Valkenberg ('11 a) and Weinberg ('28) discussed fully the relations of the mesencephalic root and its associated cells. The motor trigeminal centers were described by Sinn ('13), Ariëns Kappers ('20-'21), Black ('22), Craigie ('28), and others (p. 161).

Sensory nuclei of the trigeminal nerve. The chief sensory nucleus of the trigeminus (figs. 3 and 4) makes its appearance at the same caudal level as does the dorsal motor nucleus of this nerve. This sensory nucleus, unlike its homologue in reptiles and mammals, is not continuous with the nucleus of the descending root of the trigeminal, but is independent of this latter nuclear mass. The chief sensory nucleus lies ventrolateral to the cephalic end of the superior vestibular nucleus and just medial to the large cerebellar bundles. On its first appearance it is bluntly triangular, with the base directed dorsomedialward. This triangle of cells is made up of a central nodule of cells between two arms. The cells of the lateral arm are larger at the dorsal end, and those of the medial arm are arranged in bands along the fibers (fig. 3, right side). The lateral arm and central nodule increase to form two oval masses lying side by side with the ribbon-like medial arm along their inner surface (fig. 3, left side). The nucleus here lies in a dorsomedial, ventrolateral direction and extends almost across the peduncle between medulla and cerebellum. Farther cephalad, the cells of the more ventrolateral part of the nucleus become less dense and slightly larger. The more dorsal parts gradually disappear, while the ventral part elongates and forms more or 
less of a crescent lateral to the ventral motor nucleus of the trigeminus. It remains in the field after the disappearance cephalically of the ventral motor trigeminal group and after nucleus isthmo-opticus is well established (fig. 2). The cells of the chief sensory trigeminal nucleus on the whole are small and deeply stained. The above account is based on a study

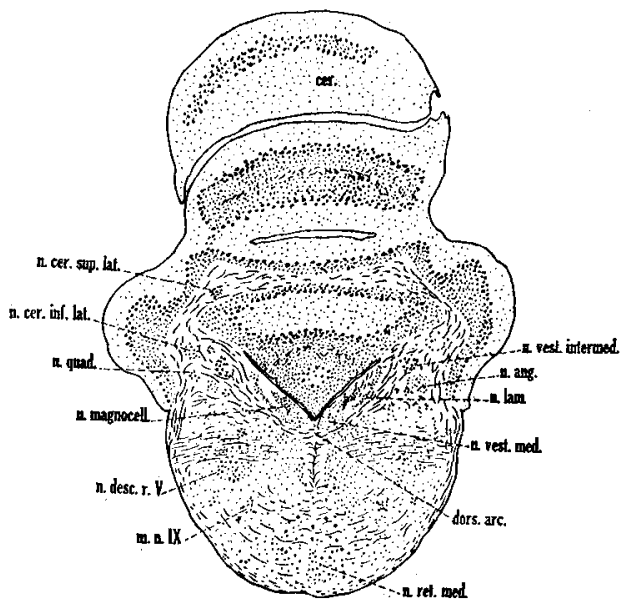

Fig. 8 Cross-section through the level of the cochlear nueleus and the motor nueleus of the glossopharyngeus in sparrow. Toluidin-blue preparation. $\times 7.5$. cer., cerebellum; dors.arc., dorsal arcuates; m.n.IX, motor nucleus of the glossopharyngeal nerve; n.ang., nucleus angularis; n.cer.inf.lat,, nucleus cerebellaris inferior lateralis; n.cer.sup.lat., nueleus cerebellaris superior lateralis; n.desc.r.V, nucleus of descending root of the trigeminal nerve; n.lam., nucleus laminaris; n.magnocell., nuclous magnocellularis; n.quad., nucleus quadrangularis ; n.ret.med., nucleus reticularis medius; n.vest.intermed., nucleus vestibularis intermedius; n.vest.med., nueleus vestibularis dorsomedialis.

of the sparrow material. Fissentially similar conditions exist in the other avian forms available for comparison. The outline of the nucleus may vary, but it occupies essentially the same position in duck, dove, parrakeet, and chicken, and the arrangement of the cells in a more or less typical rosette fashion is to be scen in all these birds.

A few cells representing the cephalic end of the descending nucleus of the trigeminal appear ventral to the vestibular 
root fibers at a level through the cephalic end of nucleus magnocellularis and where medial and lateral vestibular groups are fully developed. The number of cells gradually increases caudalward and the nucleus spreads out somewhat, so that its ventral surface lies close to the accessory nucleus of the abducens (fig. 7). As the latter fades out the nuclens of the descending root becomes more spherical (fig. 8, on left in particular). At the level of nucleus angularis (figs. 9 and 12 ) it is a relatively large nuclear group ventral to entering vestibular fibers and medial to the aseending cerebellar paths. Farther caudalward, it moves somewhat lateralward and ventralward and occupies practically the same position back to the cord (fig. 14).

The mesencephalic nuclens and root of the trigeminal are labeled on certain of the figures (figs. $1 \Delta$ and 2). Since they have been described by Weinberg ('28) from the series used in the present account, they will not receive further attention here.

Motor nucleus of the trigeminal. The ventral motor nucleus of the trigeminal (figs. 3 and 4) makes its caudal appearance in a plane through the cephalic end of the abducens nucleus, lateral to the dorsal motor nucleus of the facial. A few sections farther forward, the ventral motor nucleus of the trigeminal and the dorsal motor nucleus of the facial become slightly elongated and form at this cross-sectional level the sides of a cup with the opening directed dorsalward. Then the dorsal motor nueleus of the facial begins to disappear and the ventral motor nucleus of the trigeminal increases. This latter nucleus still remains as a single cell mass for a few sections and then divides into a medial ball of cells (the medioventral group, fig. 3) and a more elongated lateral unass (the lateroventral group, fig. 3). Along the medial boundary of the medioventral group for a part of its extent, there is a thin layer of slightly smaller cells. The medioventral group occupies the position formerly held by the dorsal motor nucleus of the facial and probably represents the combined trigemino-facial complex described by Black ('22) for Cacatua. 
The lateroventral group is the more caudal portion of the nuclear mass.

It has been possible to identify in sparrow the same groups within the motor nuclei of the trigeminal which Black ('22)

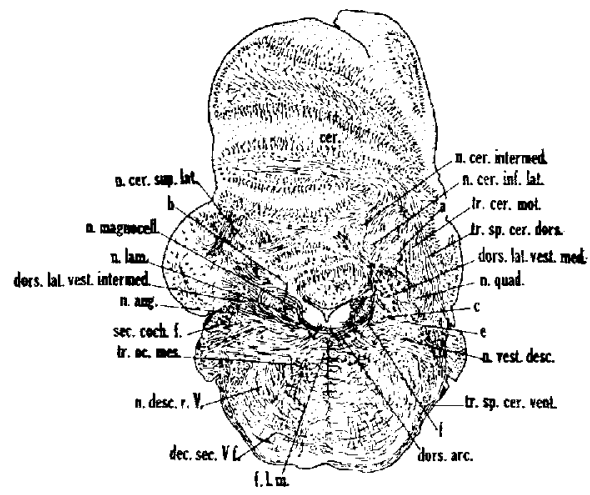

Fig. 9 Cross-section through the middle of the cochlear and vestibular centers and root fibers and the cerebellar nuclei. Pyridin-silver preparation. $\times 7.5$. $a$, fibers from lateral cerebellar nucleus to tractus cerebello-notorius; $b$, internuelear fibers between nueleus laminaris and nucleus magnocellularis; c, small. celled part of medial division of dorsolateral vestibular nuclear group; cer., cercbellum; decsec. $F$ f, decussating secondary trigeminal fibers; dors.arc, dorsal arcuates; dors.lat.vest.med., dorsolateral vestibular nuclear group, medial division; dors.lat.vest.intermed., dorsolateral vestibular nuclear group, intermediate division; $e$, fibers from lateral cerebellar nucleus to medial vestibular commis. sure; $f$, direct vestibular tractus cochleo-cerebellaris; f.l.m., faseiculus longitudinalis medialis; n.ang., nucleus angularis; n.cer.inf.lat., nucleus cerebellaris inferior lateralis; n.cer.intermed., nucleus cerebellaris intermedialis; n.cer.sup. lat., nueleus cerebellaris superior lateralis; n.desc.r. $\boldsymbol{F}$, nucleus of descending root of trigeminal nerve; n.lam., nucleus laminaris; magnocell., nuelens magnocellularis; n.quad., nueleus quadrangularis; n.vest.desc., nucleus vestibularis descendens (inferior); sec.coch.f., secondary cochlear fibers; tr.cer.mot., tractus cerebello-motorius; tr.ac.mes., tractus oceipito-mesencephalicus; tr.sp.cer.dors., tractus spino-cerebellaris dorsalis; tr.sp.cervent., tractus spino-cerebellaris ventralis.

described for Cacatua. However, there are differences in the relations of these groups in the two birds. The medioventral group (or the trigeminal component of the trigeminofacial complex) is relatively larger in sparrow than in Cacatua, for in sparrow it is not a caudal extension of the motor 
nucleus of the trigeminus behind the lateroventral group, but appears in front of the cephalic end and extends behind the caudal end of the dorsolateral portion. The cells of the medioventral group likewise exceed in number those of the other group. In sparrow the lateroventral group is lateral to the medioventral group rather than ventrolateral, as in Cacatua.

In duck the ventral motor nucleus of the trigeminus can easily be divided into medial and lateral parts. The medioventral portion extends slightly farther in a caudal direction than does the lateroventral part. This medioventral group is quite large and might easily be subdivided further, although such subdivisions would be interconnected by scattered cells. Such further divisions may well be indications of functional localization within the nucleus similar to that demonstrated for many of the motor nuclei in mammals. The medioventral part in duck is not a direct forward continuation of the dorsal motor nucleus of the facial as it is in sparrow. However, in part, the more caudal portion of the medioventral group occupies a position analogous to that held farther back by the dorsal motor nucleus of the facial nerve. Traced forward, the medioventral and lateroventral groups of the ventral motor trigeminal nucleus bear about the same relation to each other in duck that they do in sparrow, but the medioventral extends a little farther forward. It is difficult to state with certainty whether the lateroventral or medioventral portion is the larger, since the former covers the larger territory, while the latter is more compact and contains a greater number of neurons. The nuclear groups of the dorsal motor trigeminal nucleus show no marked variation in chicken from the conditions just described for duck. In dove the medioventral group is represented by cells scattered from the dorsal motor trigeminal nucleus all along the medial surface of the lateroventral group and cannot be delimited clearly from other large cells in the ficld.

A dorsal motor nucleus has been described for various birds (p. 161). 'This nucleus is present in sparrow, where its 
caudal end appears a few sections in front of the caudal end of the ventral motor nucleus of the trigeminal. It is dorsal and very slightly medial to the dorsal motor nucleus of the facial, and it disappears frontalward at the same level as does this latter nucleus. Its cells are smaller than are those of the ventral motor nucleus of the trigeminal. The dorsal motor nucleus of the trigeminal is recognizable in all the
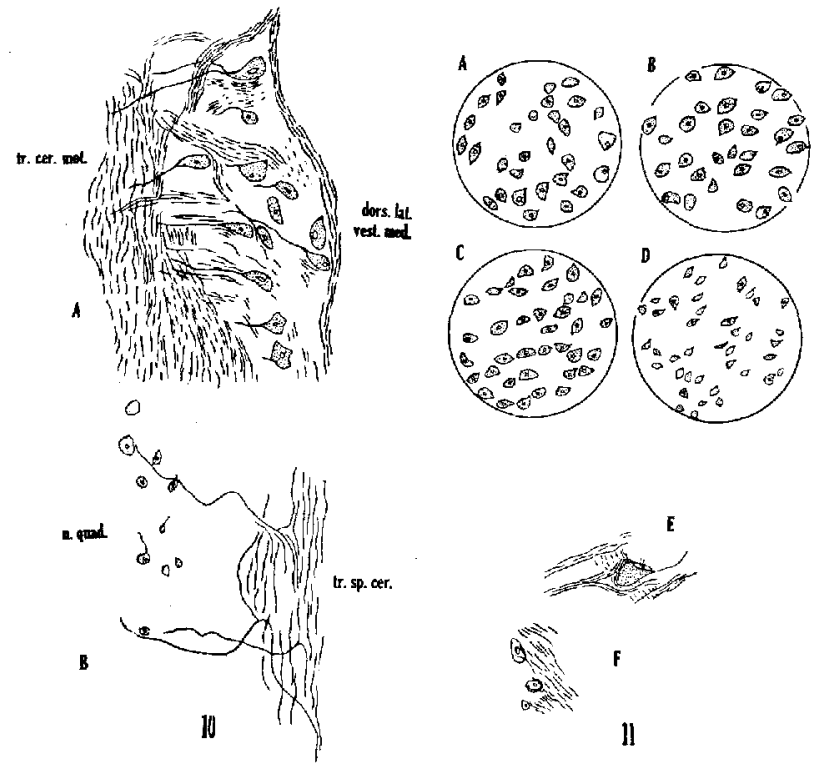

Fig. 10 A. Camera-lueida drawing of the large cells of the medial division of the dorsolateral vestibular nuclear group, showing the orientation of the dendrites at right angles to the tractus cerebello-motorius. B. Camera-Iucida drawing of the neurons of nucleus quadrangularis, showing their orientation to the spinocerebellar traet. $\times 256$. dors.lal.vest.med., dorsolateral vestibular nuclear group, medial division; n., nucleus quadrangularis; tr.ser.mot., tractus cerebello-motorius; tr.sp.cer., tractus spino-cerebellaris.

Fig. 11 A, B, C, D. Camera-lueida drawings of the cells of nuelens magnocellularis. $\times 247 . A$, medial part of the nucleus at its anterior end; $B$, lateral part of the nucleus at its anterior end; $C$, medial part of the nucleus at its posterior end; $D$, lateral part of the nueleus at its posterior end. The cells in $A, B$, and $C$ are approximately the same size; those of $D$ are smaller. $E$, neuron of nueleus tangentialis, showing synapse of incoming vestibular fibers. $\times 254$. $F$, neuron of nueleus laminaris, showing synapse of incoming cochlear fibers. $\times 249$. 
avian forms available for study, although its position varies somewhat in the different birds. Thus in dove and duck it appears to extend a little farther lateralward than in sparrow; in chicken it is placed about as far lateral as in dove, but farther dorsal than in either dove or sparrow. In parrakeet, as in sparrow, it is slightly rostral and lateral to the nucleus of the abducens.

Cutaneous sensory root of the trigeminal. Direct root fibers (figs. 3 and 4) enter the bulb lateral to the root of the facial and terminate in the chief sensory nucleus of the trigeminal. Collaterals of these fibers and other direct root fibers (fig. 3) turn backward and run toward the cord, lying in close approximation to the nuclens of the descending root of the trigeminal and terminating in synaptic relation with its neurons. van Valkenberg ('11 a) and Ariëns Kappers ('20'21) regarded the more ventral fibers of the descending root as ophthalmic and the more dorsal as mandibular, and determined that the former extended to the cord, while the latter terminated at the level of the glossopharyngeal and vagus nerves. Certainly, the more dorsal bundles in the descending root, presumably those from the maxillo-mandibular component, terminate within bulbar regions, while the more ventral bundles appear to extend at least to the beginning of the cord. Accompanying the trigeminal fibers to the chief sensory nucleus are small fascicles of the nerve which appear to swing directly dorsalward to the cerebellum (fig's. 3 and 4).

Mesencephalic and motor roots of the trigeminal. Fibers of the mesencephalic root (fig. 2) are large in bird and can be traced easily to their cells of origin (Weinberg, '28). Homolateral motor fibers arising from the caudal end of the medioventral portion of the ventral motor nucleus run dorsomedially, following a path similar to that of the facial farther caudalward, then join the fibers from the dorsal motor nucleus of the trigeminal which they accompany lateralward and ventralward to the ventrolateral surface of the bulb. In their course they are joined by fibers from the lateroventral motor nucleus of the trigeminal (fig. 4). Other bundles from the 
medioventral nucleus run directly ventrolateralward from their origin in the nucleus (fig. 3). Contralateral motor fibers are believed to be present in bird, although experimental degeneration is necessary for their unquestioned demonstration. Such contralateral fibers appear to have their origin in the lateroventral motor trigeminal nucleus at a cross-sectional

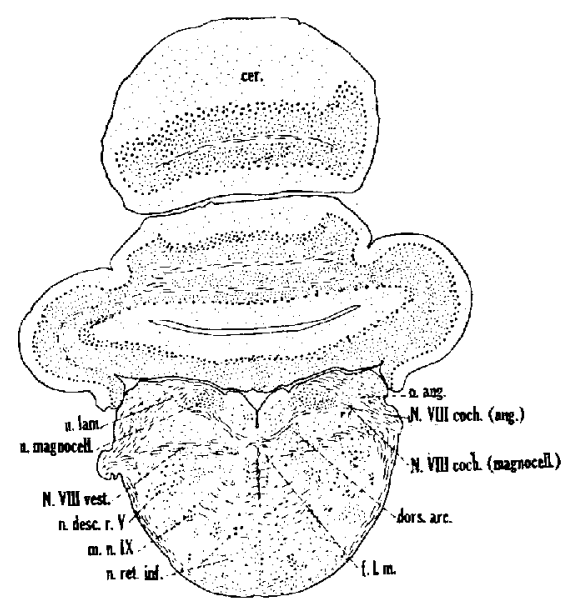

Fig. 12 Cross-section through the more posterior portions of the cochlear nuclei in sparrow. Toluidin-blue preparation. $\times 7.5$, cer., cerebellum; dors.are., dorsal areuates; f.l.m., fasciculus longitudinalis medialis; m.n.IX, motor nucleus of glossopharyngeal nerve; n.ang., nueleus angularis; ndesc.r.V, nucleus of descending root of trigeminal nerve; n.lam., nueleus laminaris; n.magnocell., nualeus magnocellularis; n.ret.inf., nucleus reticularis inferior; $N, V I I$ eoch.(ang.), cochlear nerve to nucleus angularis; n.VIII coch.(lam.), cochlcar nerve to nucleus laminaris; $N . W I I$ coch. (magnocell.), cochlear nerve to nucleus magnoecllularis; N.VIII vest., vestibular nerve.

plane passing near the frontal end of the abducens nucleus. These fibers run almost directly dorsalward along the medial contour of the cerebello-motorius component to the ventral motor nucleus of the trigeminus, then turn medialward just dorsal to the cross-cut bundles of the tractus occipito-mesencephalicus et bulbaris (fig. 4), cross the midline just dorsal to the abducens nucleus, together with the cercbello-motorius fibers, then run forward for a short distance and join the 
motor root of the trigeminal on this other side, with the fibers of which they appear to emerge. It is to be emphasized that this needs experimental substantiation. The motor root of the trigeminal emerges from the brain medial to its sensory root.

Secondary connections of the trigeminal centers

Four major groups of efferent tracts from the sensory nuclei of the trigeminal to other centers have been demonstrated in the available material. They consist of, 1) internuclear fibers, 2) trigemino-cerebellar tracts, 3) sceondary ascending trigeminal tracts (1rigemino-mesencephalic bundles, sometimes termed trigeminal lemniscus), and, 4) quintofrontal paths. Aside from internuclear connections, only cerebello-motorius fibers have been traced into the motor nuclei of the trigeminal nerve. The components will be considered in the order named.

Internuclear fibers from sensory trigeminal nuclei. Such fibers pass from the chief sensory nucleus and the nucleus of the descending root to the ventral motor nucleus of the trigeminal. Similar fibers connect the nucleus of the descending root with the motor nuclei of the facial nerve.

Trigemino-cerebellar connections. The secondary trigeminal comnections with cerebellum are numerous and correspond very closely with those described for alligator (Huber and Crosby, '26). From the chief sensory nucleus tractus trigemino-cerebellaris rectus emerging from its dorsal surface passes directly to the cerebellum (fig. 4). These uncrossed trigemino-cerebellar fibers are joined, as they emerge from the nucleus, by crossed trigemino-cerebellar bundles (fig. 4). Such crossed trigemino-cerebellar tracts arise from the chicf sensory nucleus of the trigeminal of one side, decussate in the ventral part of the bulb near their plane of origin, accumulate ventral to the chief sensory nucleus of the other side, and then turn dorsalward along the lateral side of this mucleus in order to join the homolateral trigemino-cerebellar tract. The uncrossed trigemino-cerebellar tract was 
described by Biondi ('13) for chick and by Craigie ('28) for humming bird.

In addition to these trigemino-cerebellar paths from the chicf sensory nucleus of the trigeminus, a bundle passes directly dorsalward from this nucleus, enters the anterior medullary velum (fig. 2), and decussates. This bundle is

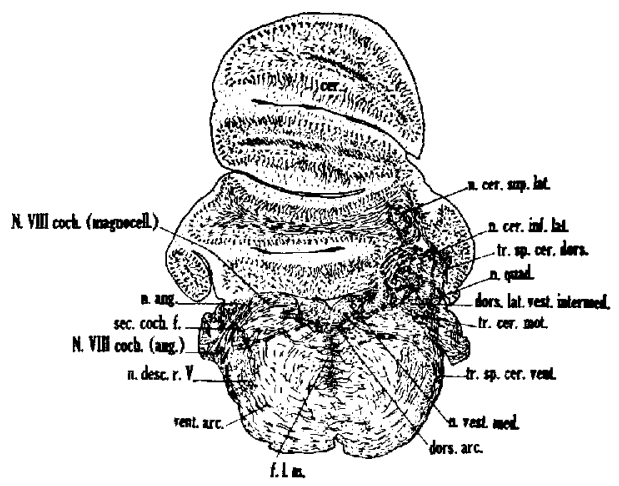

Fig. 13 Cross-section toward the caudai end of the cochlear nuclei in sparrow, slowing particularly nucleus angularis and various secondary cochlear conncctions. Pyridin-silver preparation. $\times 7.5$. cer., cerebellum; dors.are, dorsal arcuates; dors.lat.ventintermed, dorsolateral vestibular nuclear group, intermediate division; f.l.m., fascieulus longitudinalis medialis; n.ang., nueleus angularis; n.cer.inf.lat., nucleus cerebellaris inferior lateralis; n.cer.sup.lat., nucleus cerebellaris superior lateralis; ndescr.t, nucleus of descending root of trigeminal nerve; n.quad., nucleus quadrangularis; n.vest.med., nucleus vestibularis dorsomedialis; N.VIII coch.(ang.), cochlear nerve to nucleus angularis; N.FIII coch.(magnocell.), cochlear nerve to nucleus magnocellularis; sec.coch.f., secondary cochlear fibers; tr.cer.mot., tractus cerebello-motorius; tr.sp.cer.dors., tractus spino-cerebellaris dorsalis; tr.sp.cervent., tractus spino-cerebellaris rentralis; vent.arc, ventral areuates.

believed to pass to the cerebellum of the opposite side, although it could not be traced to its termination. Tractus trigemino-cerebellaris cruciatus superior has not been demonstrated for alligator.

Secondary ascending trigeminal bundle (trigemino-mesencephalic tract). Fibers having their origin in the nucleus of the descending root of the trigeminal nerve can be traced ventromedialward and slightly forward from this nucleus, 
particularly at its more cephalic levels (fig. 9). They are joined somewhat more frontalward by trapezoid fibers from nucleus laminaris. Both trapezoid and secondary trigeminal fibers cross the midline (fig. 6). After the decussation, the latter fibers are joined by homolateral secondary trigeminal fascicles from the nucleus of the descending root. At the level of the ventral motor nucleus of the trigeminal nerve the secondary trigeminal bundle thus formed occupies a position ventral to this nucleus and in close approximation with the lateral lemniscus, which fiber tract it accompanies to midbrain centers (fig. 4). Crossed secondary trigeminal fibers (fig. 4) join this rentral ascending secondary trigeminal tract (sometimes called trigeminal lemniseus) from the chief sensory nucleus of the trigeminal nerve. The tract (fig. 2) reaches the midbrain region just medial to the nucleus mesencephalicus lateralis, pars dorsalis, where it terminates in part in the area which Wallenberg ('04) calls nucleus mesencephalicus medialis and Ariëns Kappers ('20-'21), nucleus mesencephalicus lateralis, pars ventralis. Whether it has further regions of distribution it is not possible to state at present.

Quinto-frontal tract. The quinto-frontal path (fig. 2; see also Huber and Crosby paper, '29) has been followed in the pyridin-silver material of both dove and sparrow. The following account is based on sparrow. In all essentials the relations are the same as those described by Wallenberg ('98 and '03), to whom belongs the credit of having first clearly demonstrated this tract. Other accounts of it are to be found in the literature, as, for example, in the description given by Schroeder ('11) for chicken.

In the sparrow the fibers forming the quinto-frontal tract leave the cephalic half of the chief sensory nucleus along its dorsal surface. Part of the fibers swing almost directly medialward and decussate at the level of the trochlear crossing. After the decussation, they join homolateral fibers from the chief sensory nucleus, and the bundle thus formed runs forward loward higher centers. Gradually it turns ventrolatcralward and occupies a position ventral to the strio-cere- 
bellar and strio-tegmental components of the lateral forebrain bundle. It accompanies this bundle to the forebrain, where it terminates in relation with neostriatal centers and the nucleus basalis. The quinto-frontal path is illustrated in figure 2 of the present paper. Its course through thalamic and forebrain areas is figured and described for sparrow in the Huber and Crosby paper ('29).

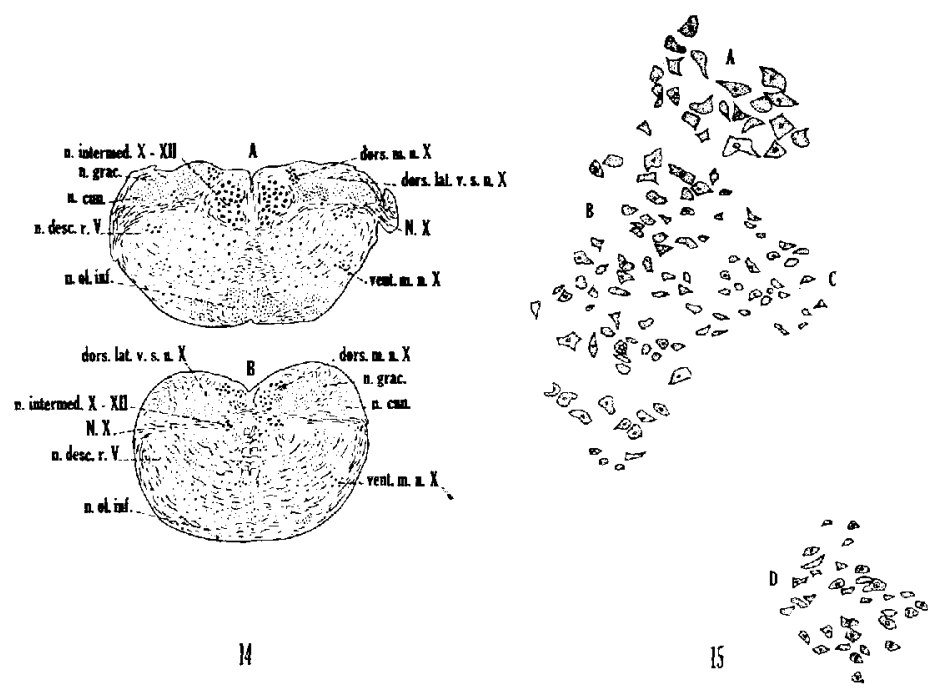

Fig. 14 A. Cross-section through the dorsal motor or efferent nucleus of the vagus and the nuelens intermedius in parrakect. $\times 7.5$. B. Cross-section through a level similar to that of $\mathrm{A}$ in sparrow. $\times 7.5$. Attention is called to the difference relatively in size of the motor nuclei in the two forms and the greater development of the inferior olivary nucleus in the parrakeet. dors.m.n.X, dorsal motor (or efferent) nucleus of vagus nerve; lors.lat.v.s.n.X, dorsolateral visceral sensory nueleus of vagus nerve; n.cun., nucleus cuneatus; n.descr.r. nucleus of descending root of trigeminal nerve; n.grae, nueleus gracilis; n.intermed.X-XII, nucleus intermedius of vagus and lypoglossal nerres; n.ol.inf., nucleus olivarius inferior; $N . X$, vagus nerve; vent.m.n.X, ventral motor nucleus of vagus retre.

Fig. 15 A, B, C. High-power camera-lueida drawing of the cell groups in the dorsal notor or efferent nueleus of the vagal and glossopharyngeal nerves. Sparrow. Toluidin-blue preparation. $\times 268 . A$, dorsolateral nuclear group of dorsal efferent nucleus of the vagus; $B$, ventromedial nuclear group of the dorsal efferent nucleus of the vagus; $C$, neurons of ventrolateral nuclear group of the dorsal efferent nucleus of the vagus; $I$, neurons of nuclear gronp forming the dorsal efferent or motor nucleus of the glossopharyngeal nerve. 
Cerebello-motorius fibers. In a plane through the anterior part of the nucleus laminaris and the superior vestibular nuclei, crossed and uncrossed cerebello-motorius fibers arise from the internal cerebellar nucleus, and possibly from the intermediate and lateral cerebellar nuclei as well (fig. 6). These fibers swing ventralward near the floor of the ventricle and partly cross in company with decussating fibers of the motor trigeminal root. They terminate in the ventral motor trigeminal nuclei of the same and the opposite side (fig. 4).

\section{Nuclei and root fibers of the facial nerve}

Sensory nucleus of the facial. Because of the poor development of taste in birds, the visceral sensory fibers of the facial are few in number, and the visceral sensory area at the level of entrance of this root is a very inconspicuous gray mass consisting of extremely small cells. This area (fig. 5) occupies a position medial and very slightly dorsal to the abducens nucleus and caudal to the dorsal motor nucleus of the trigeminal nerve. Its position is comparable to that held farther caudalward by the visceral sensory areas of the glossopharyngeal and vagal nerves.

Motor muclei of the facial. Just medial to the dorsal part of the superior olive in sparrow and only a few sections before its disappearance caudally, a few scattered cells mark the appearance of the lower end of the facial motor nucleus (fig. 7). In general, in cell character this nucleus resembles the accessory nucleus of the abducens nerve. Almost immediately this motor nucleus begins to elongate and becomes a typical ventral motor nucleus, while a group of cells dorsal to it, and from which, at the cephalic level of nucleus magnocellularis it is clearly distinct, becomes the dorsal motor nucleus of the facial nerve. As the sections are read forward the former nucleus disappcars, but the latter remains for a short time, occupying a position just medial to the rentral motor nucleus of the trigeminal nerve and almost fused with it (fig. 5). The cells of this facial nucleus are a trifle smaller than those of the trigeminal nucleus. Gradually the dorsal 
motor nucleus of the facial elongates and just before its disappearance becomes almost continuous, through scattered cells, with van Hoevell's dorsal motor nucleus of the trigeminus (fig. 3).

Both motor nuclei of the facial have been identified in duck, chicken, and parrakeet, as well as in sparrow. In duck they are readily delimited. In chicken, near their cephalic end, reticular neurons of a similar general character form a more or less continuous column of cells from the ventral reticular nucleus, through the two facial nuclei, to the dorsal motor nucleus of the trigeminal. In parrakeet the ventral motor nucleus is slightly ventrolateral to the dorsal motor nucleus of the facial, and is not clearly delimited at its cephalic end from the medioventral group of the ventral trigeminal motor nucleus.

Root fibers of the facial nerve. Efferent fibers of the facial nerve (fig. 5), arising in the ventral and dorsal motor nuclei of the nerve, run directly dorsalward. They then make a lateral turn almost at right angles to their former course and just dorsal to the cross-cut bundles of the tractus occipitomesencephalicus et bulbaris. Swinging around these bundles, they turn ventralward and, running lateral to the superior olive and medial to the trigeminal roots, emerge from the ventrolateral surface of the medulla.

Nuclear centers and root fibers of the cochlear nerve

The acoustic nerve is large in birds, the cochlear root and associated nuclear centers are well developed, and the vestibular centers are relatively larger and more highly differentiated than in other vertebrate types. This development of the vestibular areas is related, of course, to their importance in the maintenance of equilibrium. For ease of description, the cochlear centers are described first, although they do not extent as far forward as do the upper vestibular nuclei.

Nuclear centers of the cochlear nerve. All students of the bird medulla are agreed that the nucleus angularis and the 
nucleus magnocellularis are centers of termination of the cochlear nerve. A third cell mass associated with these, the nucleus laminaris, is under the influence of auditory impulses, but whether through direct root fibers, as Winkler ('07) and others thought, or indirectly by means of internuclear fibers, as Wallenberg ('98 and '00) and Ramón y Cajal ('08 b) believed, is still a matter of dispute.

Nucleus angularis (figs. 9, 12, and 13) lies at the dorsolateral angle of the medulla, at the level of entrance of the cochlear nerve. It is external to the incoming cochlear fibers which enter it from the ventromedial side (figs. 12 and 13). It consists of medium-sized, multipolar cells distinctly less round in contour than those composing the nucleus magnocellularis and, in the present material, less deeply stained. At more candal levels the nucleus angularis is separated from the nucleus magnocellularis by cochlear fibers (figs. 12 and 13), but farther cephalad the more medial portion of nucleus angularis disappears and nucleus laminaris takes its place (fig. 9). Nucleus angularis disappears cephalad at about the level of the caudal end of the abducens nucleus.

The posterior end of nucleus magnocellularis is situated at the level of entrance of the cochlear fibers (fig. 13). The cell group (figs. 13, 12, 9 to 7 ) extends forward to a plane passing through the nucleus of the abducens nerve (fig. 7). It is situated near the floor of the fourth ventricle in a position approximately midway between the midline and the taenia, and consists of mediomedial, mediolateral, and ventrolateral parts (see particularly figs, 11 and 12). The mediomedial (fig. 11, A) and mediolateral parts (fig. 11, B and C) appear farthest cephalad as small masses of cells separated from each other by a fiber band. The mediolateral part gradually increases in size, and its cells become arranged in rows with intercalated fiber bundles, which run obliquely ventromedialward, passing through the nuclear mass. In the meanwhile the small mediomedial portion (while still distinguishable) has become connected with the mediolateral part and likewise assumed a lamellar arrangement which at first appears more or less con- 
tinuous with that of the mediolateral portion. However, gradually the lamellae of the mediolateral part become more nearly horizontal in position until alternate curved lamellae of cells and fibers form the horizontal bands which characterize the nuclear mass in this region. In the series studied, the nucleus at this level is distinctly peanut-shaped (fig. 12). The mediomedial part of the nucleus is still distinguishable by the tilt of its constituent cells and fibers, but ultimately it becomes entirely fused with the mediolateral part and is indistinguishable therefrom (compare fig. 11, A, B, C). Throughout its extent the mediomedial part is small and is identical in cell type with the mediolateral part. Immediately behind the fusion of these two parts of nucleus magnocellularis the ventrolateral portion of this nucleus makes its appearance. This ventrolateral part (fig. 11, D; fig. 12) is characterized by smaller cells and by an irregular grouping of these elements. It is distinguishable throughout the remainder of the extent of the nucleus. The more caudal cells of the ventrolateral part resemble those of nucleus angularis. Nucleus magnocellularis gradually decreases in size and disappears at about the level of entrance of the cochlear fibers. The mediomedial, mediolateral, and ventrolateral parts of the nucleus are distinguishable because of differences in fiber tilt and cell grouping, rather than through fundamental cytological difference, and are consequently merely parts of a single discrete nucleus.

Ramón y Cajal described a small-celled part to magnocellularis as an external or cephalic portion, but certainly in his figure it is external and caudal and would correspond to the ventrolateral part in sparrow. He stated that, with certain modifications, the cells increased in size from the external to the internal pole. This is not apparent in the sparrow material available, the cells of the whole nucleus, excepting the ventrolateral part, being of approximately the same size.

Holmes ('03) similarly described two types of cells in magnocellularis in pigeon: large darkly stained medial ones and smaller more irregular and palely stained lateral ones. 
He stated that the lateral ones did not extend to the caudal end of the nucleus.

In avian forms studied by ns, sparrow, dove, parrakeet, duck, and chicken, the ventrolateral cells of magnocellularis are slightly smaller, paler, and more irregular than those of the remainder of the nucleus, and these cells are not apparent in the cephalic section, but only throughout the caudal part.

Nucleus laminaris (figs. 6 to 9) appears caudalward at the level of the ventrolateral part of the nucleus magnocellularis and in a plane with the motor nucleus of the facial and the caudal end of the abducens nucleus. This nucleus is of sickle shape, with magnocellularis lying somewhat in the concavity, which is directed dorsomedialward (figs. 8 and 9). In the caudal part of nucleus laminaris the cells constituting approximately the upper third of the sickle are smaller and slightly more intensely stained than those of the remainder of the cell group and are more nearly cross-cut in the transverse series, while the cells constituting the lower two-thirds or so are distinctly larger, more nearly spindle-shaped, and are longitudinally ent in the transverse series, being obviously oriented parallel to intercalated fiber bundles. Farther cephalad, the cells are more nearly alike throughout the whole nuclear mass, are approximately round in outline, and less densely packed, but even here some differentiation between dorsal and ventral portions can be made. Nucleus laminaris extends the farthest cephalad of any of the cochlear nuclei, being found still at the level of the middle portion of the abducens nucleus. Ramón y Cajal described large cells in the dorsal part of nucleus laminaris and small cells in the ventral part of this nuclear mass. In the several series of sparrow brain studied, it is evident that for this bird the opposite relations with regard to size hold true. However, the cells are oriented in relation to the tilt of the fibers, and the apparent differences in size may be due to a considerable extent to the plane of the sections. Thus, in each case these differences may be more apparent than actual. 
Associated with the cochlear centers is the superior olivary nucleus, which through its intimate relation with such centers deserves consideration here. The superior olivary nucleus makes its appearance in sparrow at the cephalic end of the glossopharyngeal portion of the nucleus ambiguus (figs. 4 to 7), while just lateral to it lies the accessory nucleus of the abducens nerve. The cell group gradually increases in size as it is traced forward, and soon forms, in cross-section, a round nuclear mass, the outer cells of which form more or less concentric rings around a central core. The cephalic end of the nucleus disappears at about the level of entrance of the most caudal part of the ventral trigeminal motor nucleus. The neurons constituting the superior olivary nuclens are small and closely packed together. Many of them are spindleshaped. This nuclear mass has been recognized by most of the workers on avian medulla oblongata.

Root fibers of the cochlear nerve. The cochlear fibers enter the dorsolateral angle of the medulla at the "iss-sectional level of their nuclei, angularis and magnocellutaris (figs. 12 and 13). The former nucleus is situated along the dorsolateral surface and the more lateral of the cochlear fibers swing lateralward and dorsalward and break up into fine bundles among the cells of the nuclear mass (figs. 12 and 1.3). The greater portion of the medial cochlear fibers and all of the caudal part of the medial group turn dorsomedialward in order to enter directly the more dorsal and caudal parts of the nucleus magnocellularis, which represents the fused mediomedial and mediolateral parts previously described. They enter the lateral side of this nuclear mass (figs. 12 and 13). The fiber bundles are large and the distribution here is very evident.

As the cochlear root is followed farther cephalad, the more ventrolateral portion of the nucleus magnocellularis receives the more medial bundles. Still farther cephalad, the nucleus laminaris intervenes between the incoming cochlear fibers and the nucleus magnocellularis. At such levels the cochlear fibers pass between the cells of the nucleus laminaris in order 
to reach the more cephalic and dorsal part of nucleus magnocellularis (fig. 13). It has been a matter of considerable dispute among neurologists as to whether or not the nucleus laminaris receives direct cochlear fibers. Winkler ('07) believed that such was the case, while Brandis ('94), Wallenberg ('00) and Ramón y Cajal ('08) were of the opinion that the fibers passed through it to nucleus magnocellularis without synapse in the nucleus laminaris. The sparrow material suggests that the major portion of the fibers do pass directly through this latter nucleus. However, fine fibers issuing from the main bundle break up into pericellular calyces around the cells of nucleus laminaris (fig. 11, E). These fine fibers are non-medullated and are in all probability collaterals of the stem fibers. Since they do not have medullary sheaths, they would not stain in degeneration material of the type made by Wallenberg. Our material does not give satisfactory evidence of the decussation of direct cochlear fibers, although in a few secti: there is a slight suggestion of such crossing. There is a uggestion also that a very few direct cochlear fibers may swing into the ventral arcuate system.

\section{Secondary connections of the cochlear centers}

With the disappearance of direct cochlear connections frontalward, internuclear relations become distinct. Fibers from the entire ventrolateral surface of the nucleus laminaris swing slightly lateralward or ventralward, as the case may be. These make up a bundle of fibers that forms a ventrolateral capsule for nucleus laminaris and then swings medialward. The most dorsal portion of this bundle, at the most medial point of nucleus laminaris, swings dorsally and establishes direct connections with the medioventral cells of nucleus magnocellularis (fig. 9). The ventral portion of this bundle continues its course medialward, contributing to the dorsal arcuate system. At the same level, fibers from the dorsomedial surface of nucleus laminaris swing dorsalward, then medialward, forming a more or less dorsal capsule for the nucleus magnocellularis. A little farther cephalad, they run into the 
dorsomedial part of nucleus magnocellularis (including a small portion of the mediomedial part; fig. 9). At this level a definite fiber bundle leaves the ventromedial part of magnocellularis and swings ventromedialward into the dorsal arcuate system (fig. 9). Farther forward, with the disappearance of the nucleus magnocellularis, the dorsomedial bundle from the nucleus laminaris continues in the same general direction and then swings medialward into the dorsal arcuates. Connections between nucleus laminaris and nucleus angularis are present throughout their common extent, and nucleus angularis likewises contributes to the dorsal arcuates.

At a cross-sectional level just above the cephalic end of nucleus magnocellularis, fibers begin to stream from the ventrolateral border of nucleus laminaris (fig. 6). These course ventralward and very slightly lateralward across the vestibular nerve root, turn medialward just dorsal of $V$, and eross at the level of the vestibular nuclei to form an ascending bundle just under the chief sensory nucleus of the trigeminal nerve. This ascending bundle, the lateral lemniscus, runs directly forward to midbrain levels and then turns dorsalward and slightly lateralward in order to terminate in the nucleus mesencephalicus lateralis, pars dorsalis. In the latter part of its course it sends collaterals to the nucleus isthmi, pars principalis (figs. 2, 4, and 6).

At the level of nucleus angularis, nucleus magnocellularis, and the root fibers of the cochlear nerve, a bundle leaves nucleus angularis, interdigitates with the cochlear root fibers, and proceeds ventrally and medially, forming a part of the ventral arcuate system (figs. $8,9,12$, and 13). According to Ariëns Kappers ('20-'21), these fibers join the lateral lemniscus, and the sparrow material indicates such a relation. This tract is the direct homologue of the secondary cochlear fibers arising from nucleus angularis in alligator (Huber and Crosby, '26). This bundle appears to be joined in sparrow by a very few direct cochlear fibers. In birds the dorsal arcuates constitute primarily an internuclear decussation which joins nucleus laminaris of one side with nucleus mag- 
nocellularis of both sides. Ramón y Cajal thought that the system was entirely commissural, but the sparrow material indicates that there are some crossed fibers that swing ventrolateralward toward the region of the lateral lemniscus. All of the fibers which cross in the dorsal commissure do not end in nucleus magnocellularis or nucleus laminaris. Some of them swing lateral to the nucleus laminaris and course toward the cerebellum. They probably constitute the path described by Bok ('15) as a cochleo-cerebellar tract which terminated in the lateral cerebellar nucleus (fig. 9, $f$ ). In the sparrow material they can be followed into the cerebellum, but it is not possible to trace them to their nucleus of termination. There is considerable evidence in the material available that a few fibers associated with the nucleus laminaris of the same side join this cochleo-cerebellar tract. These are probably homologous with the tractus cerebello-laminaris of Mesdag ('09). The direction of conduction over this latter bundle is unknown, but it is probable that it is from nucleus laminaris to the cerebellum rather than in the direction implied by the name of the tract.

\section{Vestibular nuclei and root fibers}

Vestibular nuclei. The greatest confusion exists as to the subdivision of the vestibular nuclei in avian forms. The great importance of this nerve in birds is associated centrally with the appearance of many highly differentiated vestibular areas. The work of Bartels ('25), as well as the accounts of others to be found in the literature, suggests that there is considerable variation in different birds. The present description is based on the relations as they exist in sparrow. Under the account of each nuclear group homologies have been made in so far as possible. The following nuclei have been identified and will be described in the order named:

Nucleus vestibularis tangentialis.

Nucleus vestibularis ventrolateralis (according to Bartels ('25), ventral nucleus of Deiters).

Nucleus vestibularis descendens (inferioris).

Nucleus vestibularis dorsomedialis. 
Nucleus vestibularis dorsolateralis, pars medialis, pars intermedius et pars lateralis (according to Bartels ('25), dorsal nucleus of Deiters).

Nucleus vestibularis superioris.

The nucleus tangentialis (fig. 7) of sparrow is homologous with that described by Ramón y Cajal ('08), Ariëns Kappers ('20-'21), Bartels ('25), Craigie ('28), and others. It lies at the level of entrance of the vestibular root just lateral to the ventrolateral vestibular nucleus, and consists of cells scattered among the incoming root fibers. The neurons are small (fig. 7). They are related to the incoming fibers through pericellular synapses and their neuraxes join the vestibular root.

The ventrolateral vestibular nucleus (fig. 4) is Deiters' nucleus of Wallenberg ('98, '00), Ramón y Cajal ('08), and Craigie ('28). It is the ventral nucleus of Deiters according' to the nomenclature of Bartels ('25) and is probably the homologue of the lateral vestibular or Deiters' nucleus of mammals. It is termed the ventrolateral vestibular nucleus in the present account, to distinguish it from the dorsolateral vestibular nuclear group, to which Bartels applied the name of dorsal nucleus of Deiters. In sparrow the ventrolateral vestibular nucleus consists of large, multipolar neurons which lie among the vestibular fibers medial to the tangential nucleus and ventral to the more dorsal bundles, the direct vestibular root. The nucleus disappears slightly in front of the cephalic end of the abducens nucleus. In the sparrow series available it has not been possible to subdivide this nucleus into secondary groups such as Bartels obtained in his material.

The descending or inferior vestibular nucleus (fig. 9) appears in a plane through the cephalic end of nucleus laminaris and nucleus magnocellularis. It is smaller-celled than the ventrolateral nucleus just described. It extends caudalward for a short distance and then disappears. This nucleus has been recognized by most workers on avian vestibular areas. 
The dorsomedial vestibular nucleus or nucleus triangularis (fig. 7) has been recognized by Wallenberg ('00), Holmes ('03), Ramón y Cajal ('08), Bartels ('25), Craigie ('28), and others. However, there has not been general agreement as to whether or not it is to be regarded as a vestibular center, for Ramón y Cajal was not able to trace fibers of this nerve to it, although Wallenberg, Bartels, and Craigie came to the conclusion that such fibers were present. This nucleus lies just medial to the upper end of nucleus magnocellularis and dorsal to the decussating dorsal arcuates. In sparrow it appears to receive vestibular fibers and is probably the homologue of the medial vestibular nucleus of mammals.

The dorsolateral vestibular nucleus (comprising a group of nuclei) of the present account is the dorsal nucleus of Deiters of the Bartels nomenclature. In the present contribution the dorsolateral vestibular nucleus has been subdivided into three dorsoventrally running portions, designated median division, intermediate division, and lateral division. Such subdivision and grouping of nuclei seem justified, since each subdivision appears to include related nuclear masses. Much of the work done previously on this group has been carried out with fiber rather than cell material, and the result has been that portions of a single nuclear mass have received different names, while different nuclear centers have been brought together under a single name. The homologies of the various groups, in so far as it has been possible to determine them, are as follows.

The medial division consists of, 1) a ventral, small-celled part which is the equivalent of nucleus piriformis of Ramón y Cajal ('08) and Craigie ('28), and the nucleus Deiters' dorsalis inferior of Bartels ('25); 2) a central portion of medium-sized cells, including probably the scattered cells which, according to Craigie, intervene between the nucleus piriformis and nucleus bigeminus (and perhaps also involving the nucleus vestibularis minor of Craigie) and equivalent to Bartels' nucleus Deiters' dorsalis medius; 3) a dorsal portion comparable with the medial part of noyau jumeaux 
(Ramón y Cajal, '08), a part of nucleus gemelli of Bartels, and the nucleus gemelli of Craigie as labeled by him in figure 18.

The intermediate division of the dorsolateral vestibular nucleus is the homologue of the lateral part of the noyau jumeaux of Ramón y Cajal ('08) and of the nucleus gemelli of Bartels.

The lateral division of the dorsolateral vestibular nucleus includes the nucleus quadrangularis and the nucleus vestibulocerebellaris of Ramón y Cajal ('08), terms also used by Craigie ('28), and may include the nucleus vestibulo-floccularis of Craigie ('28), although it has not been possible in the material at hand to differentiate the nucleus as a distinct nuclear mass. As will appear from subsequent pages, we have retained the term nucleus quadrangularis (Ramón $y$ Cajal, '08) to designate a relatively distinct subdivision of the lateral division of the dorsolateral vestibular nucleus. An account of the three divisions of the dorsolateral vestibular group follows.

A few small cells representing the cephalic end of the medial division of the dorsolateral vestibular nuclear group appear a little above the cephalic end of nucleus magnocellularis. These small cells belong to the ventral part of the medial division (fig. 7) and lie just lateral to nucleus laminaris and at about the same level as the cephalic limit of the descending vestibular nucleus. It is this ventral small-celled part of the division that apparently constitutes Ramón y Cajal's nucleus piriformis, or small-celled vestibular nucleus. Fibers running ventrolateralward from it with a few cells scattered among them make up his pedicle of nucleus piriformis (fig. 6).

Slightly farther caudad, a dorsal part (figs. 6 and 9) appears so that the group in cross-section takes on an elongated form. This dorsal part extends considerably dorsal of nucleus laminaris, and the previously mentioned ventral part of the medial division is lateral to the most ventrolateral part of nucleus laminaris. The dorsal third of this medial division is made up of large multipolar cells with processes in many 
cases running medialward. Ventral to these large cells is a central region of smaller cells more oblong than the cells of the dorsal area and slightly less deeply stained. As these central cells are traced caudalward they approach in size the cells of the dorsal part. By their extension lateralward across the lateral vestibular group, the dorsal and central portions of this medial division form a concavity directed lateralward and dorsalward, in which the intermediate division rests. The ventral part does not enter into the formation of this crescent-shaped mass, but joins it on its ventral surface. This ventral part extends a little farther medialward than the rest of the medial division. Farther caudalward, the central part of the nucleus disappears as the dorsal arcuates swing into its territory. The dorsal part decreases in size and a few sections farther the ventral part disappears.

At a cross-sectional level where the medial division reaches its greatest dorsoventral extent and nucleus quadrangularis (a portion of the lateral division of the dorsolateral vestibular nucleus) is well established, the cephalic end of the intermediate division appears. This latter division (figs. 7 to 9 ) lies in the concavity formed by the dorsal and central portions of the medial division and is medial to the lateral division. Its cells resemble those of the dorsal and central portions of the medial division, the greater number of them being about the size of the central portion. The neurons are rich in Nissl substance and, along with those of the dorsal and central parts of the medial division, are larger and less rounded than those in nucleus magnocellularis. Throughout its extent this division remains much the same. It consists of a somewhat circular group of cells which extends much farther caudalward than the medial division, being still in the field after the appearance of nucleus angularis of the cochlear nerve. The intermediate division of the dorsolateral vestibular nucleus is the best delimited of the vestibular nuclei.

The lateral division of the dorsolateral vestibular nuclear group (figs. 7, 8, and 9) extends farther cephalad than do the medial or intermediate divisions or any of the nuclei of 
the cochlear nerve. This lateral division is elongated dorsoventrally, but has a medial extension. Its upper part is homologous with the nucleus quadrangularis of Ramón y Cajal and others, and is here given that name (figs. 7 to 9). This latter portion is more compact than the remainder of this nuclear division and extends farther cephalad. It enters at about the same level as the caudal end of the ventrolateral vestibular nucleus and just a little behind the level of the cephalic end of the abducens nucleus. The more dorsal part of the nucleus appears first, but the nuclear mass soon extends ventralward, lateral to the intermediate division of the dorsolateral vestibular nuclear group. At the plane of its greatest dorsoventral extent, the quadrangular nucleus is elongated and very slightly crescent-shaped with the concavity directed medialward (fig. 7). Its cells are smaller and less deeply stained than those of the other two divisions, but larger and more deeply stained than those of nucleus laminaris and strikingly similar to the cells of the lateral cerebellar nucleus. The ventral part of nucleus quadrangularis disappears caudally at the cephalic limit of nucleus angularis. At a level where the medial division is clearly developed and the cephalic end of the intermediate division is just appearing, the lateral division of the dorsolateral vestibular nuclear group reaches its greatest extent. At this level just ventral to the compact cell mass thus far described as nucleus quadrangularis there is a scattered group of cells arranged more or less in circular form, which is apparently also a part of the nucleus quadrangularis as that name was used by Ramón $y$ Cajal. Among these cells are a few larger ones which are scattered ventralward and lateralward along the vestibular root fibers. Ventromedial to these diffuse cells there is a small, triangularly shaped mass of cells, lateral to the ventral part of the medial division and ventral to the intermediate group. This is probably the nucleus 'vestibulo-cérébélleux' ('08), of Ramón y Cajal and of others, although in sparrow its neurons are not larger than are those of the ventral part of the medial division (piriformis), as appears to have been 
the case in the avian material studied by that observer. This nuclear mass is found in a plane through the cephalic end of the nucleus magnocellularis.

The superior vestibular nucleus of sparrow is found at a cross-sectional level through the cephalic portion of nuclens laminaris and the ventral part of the medial division of the dorsolateral vestibular nuclear group. At this level the lateral cerebellar nucleus is clearly differentiable. Its most caudal portion is found just above the inferior vestibular nucleus, but the cells increase on the dorsal side as the cell mass is followed forward until the superior cerebellar nucleus appears as an elongated nuclear mass following the external contour of the cerebello-tegmental tract and extending dorsalward to the small-celled ventral portion of the medial division of the dorsolateral vestibular nuclear group. This portion may be considered as the medial limb of the superior vestibular nucleus. Diffuse cells lateral to the nucleus become arranged to form a lateral limb which is approximately a mirror image of the medial one just described. The arrangement of the cells is obviously due to that of the accompanying fiber bundles, but at its fullest extent the nucleus is made up of a medial and a lateral limb: the medial one has a concavity directed medialward; the lateral one, a concavity directed lateralward, and they are continuous with each other in the middle, making more or less of an ' $\mathrm{H}$ ' with the lateral cerecellar nucleus in the dorsal fork. The dorsal parts disappear first, the ventral part disappears after the appearance of sensory nucleus of the trigeminal. The cells making up the ground work of the superior vestibular nueleus are small irregular cells, not very deeply stained, but among these smaller cells, particularly in the medial limb, are slightly larger, more deeply staining cells, resembling somewhat those of nucleus quadrangularis. Nucleus vestibularis superior of sparrow is homologous with the nucleus oralis described for various birds by Bartels ('25) and for humming bird by Craigie ('28). As these observers have stated, it is probably the homologue of the mammalian superior vestibular nucleus, or nucleus of Bechterew. This nucleus is shown in figure 5. 
Vestibular root fibers. The vestibular nerve (figs. 6 and 12) enters the medulla just ventral to the cochlear nerve and dorsal to the nucleus of the descending root of the trigeminal nerve. The main bundle follows a horizontal path, and it is quite evident that certain of the fibers cross the midline. It is not possible to determine definitely their termination on the other side-possibly they go to the ventrolateral vestibular (or Deiters') nucleus. Part of the homolateral bundles terminate soon after their entrance into the bulb in pericellular eapsules around the neurons of the tangential nucleus. The neuraxes of these neurons accompany the direct fibers of the vestibular nerve. Certain vestibular fibers synapse in the ventrolateral vestibular (or Deiters') nucleus of the same side. The main vestibular bundle interdigitates with cerebello-motorius fibers and the upper fibers of the vestibular root swing dorsalward. Some of the bundles swing around the ventral border of the lateral division of the dorsolateral vestibular nucleus, contributing in their course collaterals and perhaps stem fibers to the nucleus cerebello-vestibularis, and then turn dorsally along the medial border of nucleus quadrangularis of the dorsolateral vestibular nuclear group. They distribute to both the compact and diffuse portions of nucleus quadrangularis, a portion of the lateral division of the dorsolateral vestibular nucleus.

Still farther forward, a few direct vestibular fibers reach the ventral small-celled part of the medial division of the dorsolateral vestibular nuclear group, while others appear to swing around the ventral end of this group, turn dorsally, and run medial to the medial division, helping to form a medial capsule for it. Connections are made with the cells of the medial division, while some of the bundle continues uninterruptedly to the cerebellum, making immediate connections with the inferior lateral cerebellar nucleus. Direct vestibular fibers follow the lateral contour of the medial division, making more or less of a lateral capsule for it. Connections are made with the group, while some of the fibers pass directly to the cerebellum, reaching the internal, intermediate, and lateral 
cerebellar nuclei. Farther cephalad, there are direct vestibular to intermediate division and indications of direct vestibular fibers to the superior vestibular nucleus.

\section{Secondary connections of the vestibular nerve}

The fibers arising in nucleus tangentialis pass to the ventrolateral vestibular nucleus and probably cross with decussating root fibers to the other side of the medulla. Internuclear fibers from the ventrolateral vestibular nucleus accompany the direct vestibular fibers which run to the medial division of the dorsolateral vestibular nucleus on its lateral side and to the cerebellum. The superior vestibular nucleus is connected with the inferior lateral cerebellar nucleus and perhaps with other cerebellar nuclear centers. The relations of the dorsolateral vestibular nuclear group to afferent and efferent systems is striking. The large cells of the medial division and intermediate division of this vestibular group are so oriented that their dendrites extend across the field and come into relation with both vestibular root fibers and afferent cerebellar paths on the one hand and cerebello-motorius fibers on the other hand (figs. 9 and 10). Their neuraxes could not be traced with finality, but in some cases they appear to join the efferent paths. The smaller dendrites of nucleus quadrangularis come into relation with the ascending spino-cerebellar systems (fig. 10, B). The size of their neurons and the relations of their dendrites to the fiber systems of the cerebellum give credence to Bartels' placing of the dorsolateral vestibular group with the ventrolateral vestibular nucleus as parts of the Deiters' complex. Both groups have an efferent character. There is some indication, although the evidence is not conclusive, that the ventrolateral vestibular nucleus sends fibers (probably crossed) to the medial longitudinal fasciculus and that the dorsolateral group contributes to the same bundle by way of the cerebellomotorius system. 


\section{Cerebellum}

Cerebellar nuclei. In the following account of the cerebellar nuclei in sparrow we have adopted the nomenclature used by Ramón y Cajal ('08 a) for these centers in avian forms. Four such nuclear groups are present: a lateral cerebellar nucleus, an intermediate cerebellar nucleus, an internal cerebellar nucleus, and an intercalated nucleus.

The lateral cerebellar nucleus is ordinarily divided into an inferior and a superior part, following the nomenclature of Ramón y Cajal. Craigie ('28) has labeled an inferior lateral cerebellar nucleus, but appears doubtful about the homologies for the superior nucleus. Certainly, we are agreed that his nucleus vestibulo-floccularis does not appear to be the superior lateral cerebellar nucleus. It is far more apt to be the inferior lateral cerebellar cell group.

The inferior lateral cerebellar nucleus appears lateral to the ventral small-celled part of the intermediate cerebellar group, dorsal to the superior vestibular nucleus, and about the same level as the caudal portions of the dorsal and ventral motor nuclei of the trigeminal. It appears first in cross-section as a U, with the opening dorsalward. Farther caudally, the medial prong gradually decreases in size and the lateral prong increases in number of cells (fig. 5). Later, a dorsal part appears, giving the nucleus for a few sections near the cephalic end of nucleus quadrangularis (a portion of the lateral division of the dorsolateral vestibular nucleus) the shape of a question mark (?). This part of the nucleus is made up of medium-sized cells quite closely arranged. At a level just below the appearance of the cephalic end of nucleus laminaris scattered cells occur at the dorsolateral border of the lateral cerebellar group. These cells soon become organized into two groups, one of which extends directly medialward, while the other takes a dorsolateral direction. At the level of the cephalic limit of the vestibular group, the lateral cerebellar nucleus appears to be made up of several distinct groups of similar cells, which are nevertheless intermingled 
somewhere throughout their extent. The group of cells extending dorsolateralward from the main part of the nucleus soon occupies a dorsal position and constitutes the superior lateral nucleus of Ramón y Cajal (fig. 7). This remains in the field after the disappearance caudally of the main mass of the lateral cerebellar nucleus, with the exception of a few scattered ventral cells. It has a U shape for a few sections. Ramón y Cajal described it as made up of smaller cells. A few of the neurons may be smaller, but the majority of them, in our preparations, appear similar to those of the rest of the nucleus. The group disappears caudally a few sections behind the cephalic entrance of nucleus angularis. The lateral cerebellar group extends farther ventralward and caudalward than the other cerebellar groups.

The intermediate cerebellar nucleus (figs. 7 and 9) extends slightly farther dorsalward than do any of the other cerebellar nuclear groups. It appears cephalically a few sections below the appearance of the medial cerebellar group, occupy. ing a position on the dorsolateral margin of the latter group. It extends ventralward almost immediately and lies directly lateral to the internal cerebellar group and is separated from it with difficulty. Its cells, particularly the dorsal ones, are a little larger than the adjacent internal cerebellar-group cells. The intermediate cerebellar nucleus, a few sections after its cephalic appearance, shows evidence of a lateral differentiation which, a little farther caudalward, appears as a lateral cortex of smaller, more closely arranged cells. The ventral part of the intermediate cerebellar nucleus, and particularly its lateral cortical part, is made up of cells decidedly smaller than the majority of the cells of either the internal or intermediate cerebellar nuclear groups. The large-celled part evidently constitutes van Hoevell's pars magnocellularis of the medial cerebellar nucleus, and the small-celled part, his pars parvocellularis of this same cerebellar nucleus. The whole group appears to be identical with Ramón y Cajal's nucleus intermedius. The ventrolateral cortex-like portion forms a ventrocaudal prolongation of small cells which lies 
medial to the lateral cerebellar group after the appearance of the latter. At the level of the cephalic appearance of the inferior lateral cerebellar nucleus the intermediate nucleus consists of a dorsomedial large-celled portion more medial and dorsal and a lateroventral small-celled portion. By the time the level of nucleus intercalatus is reached, the intermediate cerebellar group appears in cross-section as a greatly elongated cell column, consisting of large dorsal and small ventral cells. The intermediate nucleus extends caudally a few sections behind the cephalic limit of the nucleus magnocellularis. Frontal sections confirm Ramón y Cajal's description of nucleus intermedius very satisfactorily.

The internal cerebellar nucleus (figs. 5 and 6) appears slightly farther cephalad than the other cerebellar groups. Cross-sections at this level indicate its separation into lateral and medial portions separated from each other dorsally by incoming fibers. The group is distinguished with difficulty from the intermediate cerebellar nucleus. Throughout its extent it consists of groups of cells separated by fiber bundles. It is separated from its fellow by the elongated cerebellar ventricle, and toward its caudal end is cut off from the nucleus intermedius of the cerebellum by the nucleus intercalatus. The internal cerebellar nucleus disappears caudally in a plane through the cephalic end of the ventral part of the medial division of the dorsolateral vestibular nucleus. This internal nucleus is the 'ganglio interno ó del techo' of Ramón y Cajal ('08) and the nucleus fastigii of Craigie ('28).

The intercalary nucleus (figs. 5 and 7 ) appears cephalically at the same level as does the nucleus quadrangularis. It lies between the internal and intermediate cerebellar nuclei. The group as a whole is small, but extends slightly behind the internal cerebellar nucleus. It consists of very small cells.

Fiber connections to cerebellum. The following connections with cerebellum have been demonstrated in the series of sparrow and dove available for study: 1) spino-cerebellar tracts (dorsal and ventral), 2) olivo-cerebellar tract (p. 214), 3) inferior cerebello-reticular tract (p. 215), 4) cerebello-cochlear 
tract (p. 197), 5) cerebello-laminaris (or lamino-cerebellar) tract (p. 197), 6) vestibulo-cerebellar tracts (pp. 204 to 205), 7) cerebello-motorius system, 8) direct trigeminal root fibers (p. 183), 9) contralateral and homolateral trigemino-cerebellar tracts (p. 185), 10) contralateral trigemino-cerebellar tract, through the anterior medullary velum (p. 186), 11) cerebello-rubral tract (p. 216), 12) superior cerebello-reticular tract, 13) tecto-cerebellar tract, 14) strio-cerebellar (shown in fig. 2) (Schroeder, '13; Craigie, '28; and Huber and Crosby, '29). The major portion of these connections have been described elsewhere in the paper. The spino-cerebellar, the cerebello-motorius, and the tecto-cerebellar systems will be described briefly.

The spino-cerebellar system is extremely large in birds and constitutes a conspicuous fiber system which has been recognized for a long time and frequently described. In the bulbar region it occupies most of the lateral superficial wall of the brain, but as the level of the inferior cerebellar peduncle is reached, much of it swings dorsalward to distribute to the cerebellar cortex. Some fibers can be traced to the central nuclei of the cerebellum. The spino-cerebellar fibers, and particularly those to the nuclei, appear to be partly crossed. The more ventral part of the spino-cerebellar systems swings far forward and then turns back into the cerebellum. This represents the ventral spino-cerebellar tract. Experimental work (Friedländer, '98) has indicated that spino-cerebellar fibers in birds arise as far caudalward as the lumbar region of the cord. Cerebello-spinal fibers have likewise been described for bird. Spino-cerebellar fibers are seen in figures $3,9,10 \mathrm{~B}, 13$.

The cerebello-motorius fibers are evidently supplied from all the cerebellar nuclear groups. Farthest caudalward, the superior lateral cerebellar nucleus contributes an enormous number of fibers to these bundles. Part of these fibers follow the medial border of the spino-cerebellar tract ventralward and swing across the midline ventral to nucleus quadrangularis (a portion of the lateral division of the dorsolateral 
vestibular nucleus) in the main vestibular path. They distribute to the nucleus of the abducens on the same and on the opposite side. Another part of the bundle turns immediately ventromedialward, medial to the medial division of the dorsolateral vestibular group, and is joined in crossing by fibers from the inferior lateral cerebellar nucleus that run ventralward on both sides of the intermediate division of the dorsolateral vestibular nucleus and over its top. These distribute to vestibular nuclei. Farther cephalad, near the anterior end of the nucleus laminaris and at the same level as the superior vestibular nucleus, cerebello-motorius fibers from internal, and perhaps from intermediate and lateral cerebellar nuclei as well, swing ventrally near the floor of the ventricle. They supply the homolateral ventral motor nucleus of the trigeminal nerve. Part of them cross with decussating trigeminal fibers and distribute to the homologous trigeminal nucleus of the other side. Cerebello-motorius fibers can be followed forward to the trochlear nucleus and probably distribute to the oculomotor as well (see figs. 2, 4, 9, $10 \mathrm{~A}$ ).

Tecto-cerebellar connections have been demonstrated by various observers (Münzer and Wiener, '98; Wallenberg, '04, and others). Such fibers in sparrow swing medialward from the dorsal part of the tectum and are joined by fibers from nucleus isthmi pars principalis and perhaps from semilunaris (tractus semilunaris-cerebellaris of Craigie, '28). These bundles reach the level of the anterior medullary velum. Some of the fibers appear to enter the anterior medullary velum and decussate; others pass to the cerebellum of the same side.

Visceral sensory centers and connections of the glossopharyngeal and vagus nerves

It has been stated earlier in the present paper that, as a consequence of the relatively very poor development of gustatory sensibility, the dorsal visceral sensory nucleus of this nerve is very small and the fasciculus solitarius in the preglossopharyngeal and prevagal region is small and difficult to demonstrate. A dorsal visceral sensory area (fig. 14) near 
the floor of the ventricle and lateral to the dorsal efferent nucleus of the vagus is more readily demonstrable at the level of the glossopharyngeus and vagus. Into this region pass terminal fibers and collaterals of the sensory roots of these two nerves; other such fibers run farther medialward and come into relation with a dorsomedial visceral sensory nucleus which lies between the nucleus of the hypoglossal nerve and the dorsal efferent nucleus of the vagus. Ariëns Kappers ('20-'21) has emphasized the probable importance of this dorsomedial nucleus as a gustatory center. It is presumably homologous with the mammalian nucleus intercalatus. Sensory root fibers of both the vagus and glossopharyngeus swing caudalward in the fasciculus solitarius of the same and of the opposite side. Ramón y Cajal has pointed out that this fasciculus is very large in birds and that it consists of anteroexternal and -internal fascicles arising from the nerves of the same side and a postero-external bundle carrying crossed fibers. Caudalward, a very considerable portion of the fasciculus solitarius crosses in the commissura infima and appears to terminate in its associated gray. The relations here briefly given are similar to those described for birds by Ramón y Cajal ('08) Ariëns Kappers ('20-'21), and do not need further explanation or illustration here. Cutaneous sensory fibers entering with the vagus pass to the nucleus of the descending root of the trigeminal.

Efferent nuclei and root fibers of the glossopharyngeal, vagus, and hypoglossal nerves

Efferent nuclei and root fibers of the glossopharyngeal. These nuclei occupy a position on each side of the midline close under the floor of the ventricle, and at a cross-sectional level through the caudal end of the acoustic nerve is a group of cells which constitutes the dorsal motor or dorsal efferent nucleus of the glossopharyngeal nerve. In sparrow, at levels where it has attained its maximum size, this nucleus has become somewhat elongated dorsoventrally. The cells composing this nuclear group are of medium size, but distinctly mul- 
tipolar. A ventral motor group associated with that of the vagus gives rise to glossopharyngeal fibers. This is the homologue of nucleus ambiguus. It has been described for glossopharyngeus by Craigie ('28). The efferent root fibers of the glossopharyngeal nerve leave their nucleus on its ventrolateral border and run lateralward and slightly ventralward toward the periphery.

Efferent nuclei and root fibers of the vagus. The dorsal efferent nucleus of the glossopharyngeus is continuous caudally with the dorsal efferent nucleus of the vagus. This latter nucleus is quite large. Within it three secondary nuclear groups, based on differences in neuron size, can be distinguished. The most dorsal and cephalic of these groups eonsists of relatively large, multipolar cells. The ventromedial group has smaller cells, similar in type, size, and general appearance to those of the dorsal efferent nucleus of the glossopharyngeus. The ventrolateral group has the smallest cells found in the dorsal efferent nucleus of the vagus. These three groups are evident in the more cephalic portions of the nucleus. Farther caudalward, only cells of the type found in the ventromedial group are to be seen. Throughout most of its extent the dorsal efferent nucleus of the vagus is relatively large, but at its caudal end it is smaller than the nucleus intermedius. Root fibers arise from all three cellular groups within the dorsal efferent nucleus of the vagus, although the greater number appear to have their origin from the more ventrolateral portion. In their course toward the periphery they follow a course similar to that of the glossopharyngeal. Part of the vagus fibers, in the sparrow material, appear to arise from nucleus intermedius. A ventral motor group, simjlar to that indicated for the glossopharyngeal nerve, and continuous with it, was recognized for the vagus, giving rise to certain of the vagus fibers (see figs. 14 and 15 ).

Nucleus intermedius (fig. 14). At a cross-sectional level through the caudal end of nucleus magnocellularis and through the cochlear root, a few cells appear ventral and lateral to the dorsal efferent nuclens of the vagus. These cells 
mark the cephalic end of the nucleus intermedius. As it is traced caudalward, this nucleus gradually increases in size, but even at its greatest extent this nucleus is much smaller in sparrow than is the dorsal efferent nucleus of the vagus. Its cells are multipolar and are larger than any of those previously described for the vagal or glossopharyngeal nerves. Toward its caudal end the nucleus elongates, becoming continuous through a few scattered cells with the caudal end of the dorsal vagus nucleus. At this level it extends ventralward almost to the ventral hypoglossal nucleus, assuming a position lateral to it. For a few sections nucleus intermedius has a ventrolateral projection of scattered cells which may represent the ventrolateral vagus nucleus of Brandis ('93), Ariëns Kappers ('20-'21), and Black ('22). These cells are scattered along a ventrolateral line toward the periphery, and a few of them group together caudalward to form a slight nucleus near the surface.

The ventral hypoglossal nucleus of Brandis ('93) is a forward continuation of the ventral motor column of the cord. It extends rostrally to about the middle of the nucleus intermedius.

Root fibers of the hypoglossal. Root fibers for the hypoglossal nerve have their origin from the ventromedial portion of the homolateral and perhaps of the contralateral nucleus intermedius. Others arise unquestionably from the ventral hypoglossal nucleus, and here again some of the root fibers appear to come from the nucleus of the other side. The emerging fibers run almost directly ventralward to the periphery.

The same nuclei which have been described for the glossopharyngeal, vagus, and hypoglossal nerves in sparrow can be recognized in all the available avian material. Duck, dove, and chicken show the three types of cells characteristic of the dorsal efferent nucleus of the vagus as described for sparrow. In all these forms this latter nucleus is much larger than nucleus intermedius. Parrakeet shows only one type of cell in the dorsal efferent nucleus of the vagus, and nucleus inter- 
medius is much the larger of the two nuclei. In duck, chicken, and dove, as well as in sparrow, the two nuclei are in contact at their caudal ends.

\section{The inferior olivary nucleus}

A little behind the cephalic end of the intermedius nucleus, the most cephalic portion of the inferior olive (fig. 14) appears in sparrow. It lies on each side of the medial raphé close to the ventral surface of the medulla. The cells are small, closely packed, and not very deeply stained. A few sections farther caudad, a more spherical group of similar cells appears dorsal to the former ventral group. The two groups become continuous with each other, forming a medial column of cells on each side of the ventral raphé. A ventral lateral projection appears, followed by a dorsal lateral one slightly farther back. At a section through its fullest extent the inferior olive shows as a mass of gray made up of a medial column of cells and dorsal and ventral lamellae extending lateralward and continuous with each other at their lateral extremities. The ventral layer is smaller and disappears caudally, while the dorsal layer remains very prominent.

The inferior olivary nucleus is a prominent group of cells in all of the available avian forms. It is similar in all of them, but much more sharply differentiated in parrakeet than in sparrow. Connections between the cerebellum and the inferior olive are particularly clear in the Weigert series.

\section{Reticular nuclei}

The reticular nuclei of the medulla may be divided in sparrow into inferior, medial, and superior groups, as they have previously been divided for other birds (Ramón y Cajal, '09; van Hoevell, '11).

The inferior reticular nucleus (fig. 12) lies at the level of the vagus nuclei and extends forward to the caudal level of the cochlear nuclei. Its cells are somewhat smaller than those of the other reticular nuclei, particularly those close to the 
raphé, which are the smallest of the group. The largest cells of the inferior reticular nucleus are found in the ventrolateral portion of this nuclear area. Cerebello-reticular fibers connect this group with the cerebellar nuclei.

The medial reticular nuclei (figs. 5, 7, and 8) lie in the vestibular region. Their cells are scattered on either side of the midline over an area which lies between the motor nuclei of the facial nerve and ventral to the nucleus of the abducens. Some of the cells extend even farther lateralward and reach the region under the superior olivary nucleus. The cells of the medial reticular nuclei are large, multipolar neurons.

The superior reticular nucleus consists of a trigeminal and an isthmal portion. The trigeminal reticular nucleus at the level of the ventral motor nucleus of the trigeminal consists of a well-developed group of relatively large cells. These cells lie between the motor nucleus of the trigeminal, the dorsal motor nucleus of the facial, and the midline. They have a considerable extent in front of the level of the dorsal motor nucleus of the facial, where they occupy the position formerly held by this latter nuclear group.

The trigeminal portion of the superior reticular nucleus (fig. 3) is continuous by means of scattered cells with the isthmal portion of that nucleus. This isthmal group lies at the level of the abducens nucleus, occupying the same relative position as that held by the trigeminal group farther caudalward. The cells of the isthmal portion of the superior reticular nucleus are about the same size, but more scattered than those of the trigeminal portion of this cell mass.

Nucleus reticularis mesencephali lies still farther forward in a transverse plane through the level of the oculomotor nuclei. The cell mass consists in part of scattered cells which may extend rather far lateralward. With this reticular group belong the red nucleus and probably the interstitial cells of Ramón y Cajal ('09). The red nucleus in birds is a conspicuous cell mass somewhat round or oval in outline, but surrounded by scattered cells. Its cells are large and deeply 
staining. It has been identified many times in birds. As in mammals, it receives fibers from the cerebellum by way of a crossed cerebello-rubral path. Accompanying cerebelloreticular or tegmental fibers supply the more scattered cells of the nucleus reticularis mesencephali.

\section{The posterior funicular nuclei}

The posterior funicular nuclei have been described for many vertebrate forms, including birds, by Zeehandelaar ('21). Our cell material can add little that is instructive to the study of this group. The nucleus gracilis (nucleus of Goll) and the nucleus cuneatus (nucleus of Burdach) were identified in the various birds (fig. 14). A nucleus of Blumenau is indicated in certain birds, for example, in chicken, as Zeehandelaar ('21) has pointed out. The medial nucleus (sometimes called the Schwanzkern) is particularly evident in the parrakeet material.

Secondary connections can be traced from these nuclei across the midline where they form an ascending tract, which it has not been possible at present to trace to its termination. This is undoubtedly the bulbo-thalamic tract obtained by Wallenberg ('04) in degeneration preparations and traced by him forward to the medial capsule of nucleus rotundus, to nucleus intercalatus, and to other thalamic centers.

\section{SUMMARY AND CONCLUSIONS}

The points to be emphasized particularly with respect to the foregoing account may be summarized briefly as follows:

1. The eye-muscle nuclei are large and very well differentiated-a fact to be associated not only with the size of the muscles they supply, but also with the richness and variety of their secondary connections. They are associated not only with optic tectal centers and with each other through the mediation of the medial longitudinal fasciculns, but with auditory centers, through the connection of the oculomotor with the nucleus mesencephalicus lateralis, pars dorsalis, and the 
abducens with the peduncle of the superior olive. Connections with the ectomammillary nucleus and with the special avian nucleus isthmo-opticus further enrich their internuclear relations. The connections of this last-mentioned nucleus with the oculomotor centers are particularly with the EdingerWestphal nucleus and probably for carrying of impulses to the nucleus. The eye-muscle nuclei are put under the influence of impulses from the cerebellum by way of cerebello-motorins fibers to the abducens and trochlear nuclei and possibly also to the oculomotor nuclei.

2. The tecto-bulbar systems, consisting of crossed and uncrossed dorsal and ventral paths, are highly developed in birds.

3. The sensory trigeminal centers are represented in sparrow by a chief sensory nucleus, a nucleus of the descending root, and a nucleus of the mesencephalic root. The motor fibers of the nerve arise from a ventral and a dorsal motor trigeminal center. The cutaneous sensory nuclei of this nerve are connected with the motor trigeminal and facial centers by internuncial fibers; with the cerebellum, by a series of crossed and uncrossed trigemino-cerebellar paths; with the tectum, by homolateral and contralateral trigeminomesencephalic (or trigeminal lemniscus fibers), and with forebrain, by a quinto-frontal path. The mesencephalic root of the trigeminal has the relations typical for higher vertebrates. Homolateral and possibly contralateral root fibers arise from the motor nuclei of the trigeminal. These latter nuclei are placed under the influence of the synergic action of the cerebellum by way of cerebello-motorius paths. The position of the motor trigeminal and facial nuclei close to the nucleus of the descending root of the trigeminal indicates the importance in the reflex pattern of the bulb of the internuclear connections between these cell groups. It is an illustration of the action of the principle of neurobiotaxis, as Ariëns Kappers has emphasized. According to this writer (and to Craigie, '28), the operation of neurobiotactic principles determines the dorsal position of the chief sensory trigeminal nucleus close to the vestibular centers. 
4. The vestibular centers are very highly developed in bird. There can be demonstrated a ventrolateral vestibular nucleus - the homologue of the mammalian lateral vestibular nucleus; a dorsomedial vestibular nucleus-the representative probably of the medial or principal nucleus of higher forms; and descending or inferior and superior vestibular nuclei, homologous with similarly termed nuclei in mammals. In addition to these, there appear in birds a tangential nucleus and a large dorsolateral vestibular nucleus, consisting of several nuclear groups. These apparently have no direct equivalents in other forms. Bartels considered the dorsolateral group as a part of the Deiter's' complex. We would likewise regard it as representative of an increase in the efferent type of vestibular nuclei and so more closely related to the lateral than to the other vestibular groups.

5. The cerebellar nuclei in birds are very well developed. They are, in general, comparable to the cerebellar nuclei of mammals, as has been pointed out by various observers. The connections of the cerebellum have been given on page 208 and need not be restated here.

6. The cochlear connections are very similar to those found in reptiles, and do not need particular emphasis here. It is of some importance that, although the bulbar centers of this nerve are larger, the lateral lemniscus has increased very little in size compared with that of reptiles. A very distinct peduncle of the superior olive is present, and there are other bulbar connections. These points emphasize the fact that much of the increased differentiation here is looking toward more effective reflexes rather than richer connections to higher centers.

7. The sensory roots of the branchial nerves carry very little gustatory sensibility. The presence of a very large crossed and uncrossed fasciculus solitarius and its relations with commissura infima lend support to the view that this tract is associated primarily with general visceral sensibility.

8. The motor nuclei of the facial, glossopharyngeal, and vagal nerves are highly differentiated. These nuclei vary 
somewhat in position and size in the various birds, just as they do in mammals. A clear illustration of this variation is to be found in the relatively greater size of the nucleus intermedius in parrakeets than in sparrow (fig. 14). The difference in size is associated probably with the greater development of the tongue musculature in the former bird than in the latter.

9. A very well-differentiated inferior olive is present in birds concurrent with the very high degree of development of the cerebellum in these forms. The reticular nuclei follow the pattern common to higher vertebrates.

In general, it may be said of avian forms that they show a particularly high degree of development of the reflex centers; of the brain stem. There appears to be a very special elaboration of the centers and paths on the efferent side of the arc. Ascending fiber systems are present, but such systems are neither as large nor as complex as the degree of differentiation of the primary and secondary centers of the brain stem would lead one to expect.

\section{BIRLIOGRAPHY}

ARIËNs KAPPERS, C. U. 1908 Weitere Mitteilungen bezüglich der phylogenetischen Verlagerung der motorischen Hirnnervenkerne. Der Bau des autonomen Systemes. Folia Neurobiol., Bd. 1, S. 157-172.

1910 The migrations of the motor cells of the bulbar trigeminus, abducens and facialis in the series of vertebrates and the differenees in the course of their root fibers. Verh. der Kon. Akad. v. Wetensehappen, Amsterdam, Tweede Sectie, vol. 16, no. 4, pp. 1-195.

1912 Weitere Mitteilungen über Neurobiotaxis. VII. Die phylogenetische Entwicklung der motorisehen Wurzelkerne in Oblongata und Mittelhirn. Folia Neurobiol., Bd. 6, Sommerergänzungsheft, S. 1-142.

1913 Phenomena of neurobiotaxis in the central nervous system. Transactions of the XVII International Congress of Medieine, London.

1914 Der Gesehmack, perifer und central, zugleich eine Skizze der phylogenetisehen Veränderungen in den sensibelen VII, IX und $X$ Wurzeln. Psych. en Neur. Bladen, vol. 18, pp. 82-138.

1920-1921 Die vergleichende Anatomie des Nervensystems der Wirbeltiere und des Menschen. Bohn, Haarlem.

1928 Three lectures on neurobiotaxis and other subjects delivered at the University of Copenhagen. Levin \& Munksgaard, Copenhagen. 
BARTELS, M. 1925 Über die Gegend des Deiters und Bechterewskernes der Vögeln. Zeits. Anat. u. Entwick., Bd. 77, S. 726-784.

BECCARI, NELLo 1923 Il centro tegmentale o interstiziale ed altre formazioni poco note nel mesencefalo e nel diencefalo di un rettile. Areh. Ital. di Anat. e di Embr., vol. 20, no. 4, pp. 560-619.

Biond, G. 1913 I nuclei d'origine e terminali del nervo trigemino nel pollo. Rev. Ital. di Neuropat., Psich., ed Elettroterapia, vol. 6. (Quoted from Craigie, '28).

Black, Davidson 1922 The motor nuelei of the cranial nerves in phylogeny. A study of the phenomena of neurobiotaxis. IV. Aves. Jour. Comp. Neur., vol. 34, pp. 233-275.

BoK, S. T. 1915 Die Entwieklung der Hirmerven und ihrer zentralen Bahnen. Die stimulogene Fibrillation. Folia Neurobiol., vol. 9, pp. 475-565.

Boyce, R., AND Warrington, W. B. 1898 Observations on the anatomy, physiology and degenerations of the nervous system of the bird. Proc. Roy. Soc., vol. 64, pp. 176-179.

Brandis, F. 1893 Untersuchungen über das Gehirn der Vögel. Ursprung der Nerven der Medulla oblongata. Arch. f. mikr. Anat., Bd. 43, $\mathrm{S}$. 96-116.

1894 Untersuehungen über das Gehirn der Vögel. Ursprung der Nerven der Medulla oblongata. Arch. f. mikr. Anat., Bd. 43, S. 96-116. 1895 Untersuchungen über das Gehirn der Vögel. III. Der Ursprung des $\mathrm{N}$. trigeminus und der Augenmuskelnerven. Areh. f. mikr. Anat., Bd. 44, S. 534-555.

BroUwER, B. 1913 Über das Kleinhirn der Vögel, nebst Bemerkungen über das Jokalisationsproblem im Kleinhirn. Folia Neurobiol, Bd. 7, $\mathrm{s}$. 349-377.

Craigie, E. Horne 1928 Observations on the brain of the humming birit (Chrysolampis mosquitus Linn. and Chlorostilbon earibaeus Lawr.). Jour. Comp. Neur., vol. 45, no, 2, pp. 377-483.

Ednaer, L. 1908 Vorlesungen über den Bau der nervösen Zentralorgane. 7te Aufl., Leipzig.

Edinger, L., With Wallenberg, A., ANd Holmes, G. 1903 Untersuehungen über die vergleichende Anatomie des Gehirns. 5. Das Vorderhirn der Vögel. Abhandl. der Senckenbergischen Naturf. Gesellsch., Bd. 20, No. 4, S. $343-426$.

Frifdtänder, A. 1898 Untersuchungen über das Rückenmark und das Kleinhirn der Vögel. Neur. Zentrabl., Bd. 17, S. 351-360 und 397-409.

Gage, Susanne Phelps 1895 Comparative morphology of the brain of the soft shelled turtle (Amyda mutica) and the English sparrow (Passer domesticus). Proc. Am. Mier. Soc., vol. 17, pp. 185-238.

Herrick, C. J. 1893 Illustrations of the surface anatomy of the brain of certain birds. Laboratory notes from Denison University. Jour. Comp. Neur., vol. 3, pp. 171-176.

HoLmes, G. 1903 . On the comparative anatomy of the nervus acusticus. Trans. Roy. Irish Acad., vol. 32, sect. B, pp. 101-144.

HUBER, G. CARL 1927 New method of fixation and staining of the central nervous system for purpose of study of eytoarchitecture. Contributions to Medical Science. Dedicated to Aldred Scott Warthin, pp. 1-12. 
Huber, G. Carl, and Crosbr, Elizabeth C. 1926 On thalamie and tectal nuclei and fiber paths in the brain of the American alligator. Jour. Comp. Neur., vol. 40, pp. 97-227.

1929 The nuelei and fiber paths of the avian diencephalon, with consideration of telencephalic and certain mesencephalie centers and connections. Jour. Comp. Neur, vol. 48, pp, 1-225.

Hunter, J. I. 1923 The forebrain of Apteryx australis. Pros. Kon, Akad. v. Wetens. te Amsterdam, vol. 26, pp. 807-824.

Ingvar, Sven 1918 Zur Phylo- und Ontogenese des Kleilihirns. Folia Neurobiol., Bd. 11, S. 171-495.

Jelgersma 1889 Handelingen van het tweede Nederlandisch Natuur en Geneeskundig Congres. Leiden. (Quoted from Brouwer, '13.)

1896 De verbindingen van de groote hersenen bij der vogels met de oculomotoriuskern. Feestbundel uitgegeven doore Nederlandsche Vereeniging von Psychiatrie, vol. 49, pp. 241-250.

KaLISCHER, OTTo 1901 Weitere Mitteilung zur Grosshirnlocalization bei den Vögeln. Sitzungsberichte der Kgl. Preuss. Akad. der Wissensch., Bd. 1, S. $428-439$.

1905 Das Grosshirn der Papageien in anatomischer und physiologisehe Beziehung. Abhandl. der Kgl. Preuss. Akad. der Wissensch., Abh. 4, S. 1-105.

Koox, F. H. 1916 The inferior olive in vertebrates. Folia Neurobiol, Bd, 10, S. 205-369.

Kosaka, K., Und HiRalwa, K. 1915 Zur Anatomie der Sehnervenbahmen und ihrer Zentren. Folia Neurobiol., Bd. 9, S. 367-389.

KosaKA, K., UND YagITA, K. 1903 Experimentelle Untersuehungen über die Ursprünge des Nervus hypoglossus und seines absteigenden Astes. Jahr. f. Psychiat. u. Neurol., Bd. 24, S. 150-189.

LAPICQUe ET Girano 1906 Poids des diverses parties de l'elicéphale chez les oiseaux, Compt. Rend. de la Soe. de Biol. de Paris, T. 60, no. 25, pp. 30-33.

Mesdat, T. M. 1909 Bijdrage tot de ontwikkelings gesehiedenis van de struetuur der hersenen bij het Kipembryo. Dissertation, Amsterdam, pp. $1-153$.

MÜnzer, E., und WiEñe, H. 1898 : Beiträge zur Anatomie und Physiologie des Centralnervensystems der Taube. Monatschr. f. Psychiat. u. Neurol., Bd. 34 , S. $379-406$.

MURPHY, C. O. 1900 Die morphologische und histologische Entwieklung des Kleinhirns der Vögel. Inaugural Dissertation, Berlin. (Quoted from Ingvar, '18.)

PAPEZ, JAMES W. 1929 Comparative neurology. Thomas Y. Corwell Company. New York.

Preziuso, L. 1924 Sul nucleo acessorio del nervo abducente in alcuni vecelli e mammiferi. Nuovo Ereolani. (Quoted by Craigie, '28.)

RAMON y GAJAL, S. R. 1908 a Los ganglios centrales del cerebelo de las aves. Trab. lab. invest. biol. Madrid, vol. 6, pp. 177-194.

1908 b Les ganglions terminaux dn nerf aeustique des viseaux. Trab. lab. invest. biol. Madrid, vol. 6, pp. 195-225. 
RAMón y CAJAL, S. R. 1909 Contribucion al estudio de los ganglios de la substancia reticular del bulbo, con algunos detalles conciernientes a los fows motores $y$ vias reflejas bulbares y mesocefalicas. Trab. lab. invest. biol. Madrid, vol: 7, pp. 259-284.

RUBASCHKIN 1903 ẗber die Beziehungen des Nervus trigeminus zur Riechschleimhaut. Anat. Anz., Bd. 22, S. 407-41.5.

SCHEPMAN 1918 De octovo-laterale zinhirgen en hume verbindungen in de hersenen der vertebraten. Dissertatie Amsterdam. (Quoted from Ariëns Kappers, '20-'21.)

Schroeder, K. 1911 Der Faserverlauf im Vorderhirn des Huhnes. Jour. f. Psychol. u. Neurol., Bd. 18, S. 115-173.

Sinv, R. 1913 Beitrag zur Kenntnis der Medulla oblongata der Vögel. Monatschr. f. Psychiat. u. Neur., Bd. 33, S. 1-39.

TernI, T. 1921 Richerche sul nervo abducente e in special modo intorno al significato del suo nueleo acessorio d'origine. Folia Neurobiol., vol. 12, pp. 277-327.

TURNer, C. H. 1891 Morphology of the avian brain. Jour. Comp. Neur., vol. 1, pp. 39-92. Morphology of the avian brain (con't). Jour. Comp. Neur., vol. 1, pp. 107-133.

van Hownes, S. J. L. D. 1911 Remarks on the reticular cells of the oblongata in different vertebrates. Proe. Kon. Akad. Wetensch., vol, 12, S. $1047-1065$.

vaN VALKENBURG, C. T. 1911 a Zur Kenntnis der Radix spinalis Nervi trigemini. Monatschr. f. Psych, u. Neur., Bd. 29, S. 407-437.

$1911 \mathrm{~b}$ Zur vergleichenden Anatomie des mesencephalen Trigeminusanteils. Folia Neurobiol., Bd. 5, s. 360-418.

Wallenberg, A. 1898 a Die secundäre Acusticusbahn der Taube. Anat. Anz., Bd. 14, S. 353-369.

$1898 \mathrm{~b}$ Eine Verbindung caudaler Hirnteile der Taube mit dem Striatum. Neurol. Zentralblatt, Bd. 17, No. 7, 8. 300-302.

1900 Über zentrale Endstätten des Nervus octavus der Taube. Anat. Anz., Bd. 17, S. 102-108.

1903 Der Ursprung des Tractus isthmo-striatus (oder bulbo-striatus) der Taube. Neurol. Centralbl., Bd. 22, S. 98-101.

1904 Neue Untersuchungen über den Hirnstamm der Taube. Anat. Anz., Bd. 24, s. 142-155 und 357-369.

WeINBERG, ERNST 1928 The meseneephalic root of the fifth nerve. A comparative anatomical study. Jour. Comp. Neur., vol. 46, no. 2, pp. $249-405$.

Williams, E. W. 1908 Vergleichend-anatomisehe Studien über den Bau und die Bedentung der Oliva inferior der säugetiere und Vögel. Arbeit. a. d. Neur. Instit. an der Wiener Universität, Bd. 17, S. 118-149.

WINKLER, CoRNELIS 1907 The central course of the nervus octavus and its influence on motility. Reprinted in Opera Omnia, vol. 4, pp. 359-535. Bohn, Haarlem. 1918.

Yoshimura, K. 1910 Experimentelle und vergleichend-anatomische Untersuchungen über die untere Olive der Vögel. Arbeit. a. d. Wiener Universität, Bd. 18, S. 46-59.

ZEEHANDELAAR, I. 1921 Ontogenese und phylogenese der Hinterstrangkern in Verband mit der Sensibilität. Folia Neurobiol., Bd. 12, s. 1-133. 